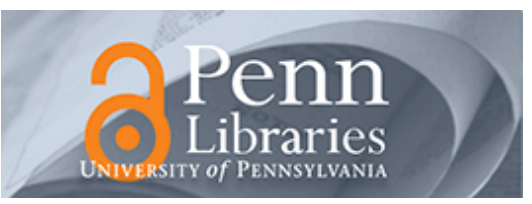

University of Pennsylvania

ScholarlyCommons

7-5-2004

\title{
MINMOD Millennium: A Computer Program to Calculate Glucose Effectiveness and Insulin Sensitivity From the Frequently Sampled Intravenous Glucose Tolerance Test
}

Ray C. Boston

Darko Stefanovski

University of Pennsylvania, sdarko@vet.upenn.edu

Peter J. Moate

Anne E. Sumner

Richard M. Watanabe

See next page for additional authors

Follow this and additional works at: https://repository.upenn.edu/vet_papers

Part of the Medical Biotechnology Commons

\section{Recommended Citation}

Boston, R. C., Stefanovski, D., Moate, P. J., Sumner, A. E., Watanabe, R. M., \& Bergman, R. N. (2004). MINMOD Millennium: A Computer Program to Calculate Glucose Effectiveness and Insulin Sensitivity From the Frequently Sampled Intravenous Glucose Tolerance Test. Diabetes Technology \& Therapeutics, 5(6), 1003-1015. http://dx.doi.org/10.1089/152091503322641060

This paper is posted at ScholarlyCommons. https://repository.upenn.edu/vet_papers/142

For more information, please contact repository@pobox.upenn.edu. 


\title{
MINMOD Millennium: A Computer Program to Calculate Glucose Effectiveness and Insulin Sensitivity From the Frequently Sampled Intravenous Glucose Tolerance Test
}

\author{
Abstract \\ The Bergman Minimal Model enables estimation of two key indices of glucose/insulin dynamics: glucose \\ effectiveness and insulin sensitivity. In this paper we describe MINMOD Millennium, the latest Windows- \\ based version of minimal model software. Extensive beta testing of MINMOD Millennium has shown that \\ it is user-friendly, fully automatic, fast, accurate, reproducible, repeatable, and highly concordant with past \\ versions of MINMOD. It has a simple interface, a comprehensive help system, an input file editor, a file \\ converter, an intelligent processing kernel, and a file exporter. It provides publication-quality charts of \\ glucose and insulin and a table of all minimal model parameters and their error estimates. In contrast to \\ earlier versions of MINMOD and some other minimal model programs, Millennium provides identified \\ estimates of insulin sensitivity and glucose effectiveness for almost every subject. \\ Disciplines \\ Medical Biotechnology \\ Author(s) \\ Ray C. Boston, Darko Stefanovski, Peter J. Moate, Anne E. Sumner, Richard M. Watanabe, and Richard N. \\ Bergman
}




\title{
MINMOD Millennium: A Computer Program to Calculate Glucose Effectiveness and Insulin Sensitivity from the Frequently Sampled Intravenous Glucose Tolerance Test
}

\author{
RAY C. BOSTON, Ph.D., ${ }^{1}$ DARKO STEFANOVSKI, B.Sc., ${ }^{1}$ PETER J. MOATE, M.Agr.Sc., ${ }^{1}$ \\ ANNE E. SUMNER, M.D., ${ }^{2}$ RICHARD M. WATANABE, Ph.D., ${ }^{3}$ \\ and RICHARD N. BERGMAN, Ph.D. ${ }^{4}$
}

\begin{abstract}
The Bergman Minimal Model enables estimation of two key indices of glucose/insulin dynamics: glucose effectiveness and insulin sensitivity. In this paper we describe MINMOD Millennium, the latest Windows-based version of minimal model software. Extensive beta testing of MINMOD Millennium has shown that it is user-friendly, fully automatic, fast, accurate, reproducible, repeatable, and highly concordant with past versions of MINMOD. It has a simple interface, a comprehensive help system, an input file editor, a file converter, an intelligent processing kernel, and a file exporter. It provides publication-quality charts of glucose and insulin and a table of all minimal model parameters and their error estimates. In contrast to earlier versions of MINMOD and some other minimal model programs, Millennium provides identified estimates of insulin sensitivity and glucose effectiveness for almost every subject.
\end{abstract}

\section{INTRODUCTION}

B ERGMAN ET AL. ${ }^{1}$ developed a nonlinear "minimal" model to mathematically describe how glucose and insulin together control the production and disposal of glucose in the body. The aforementioned model enables estimation of two key indices of glucose/insulin dynamics: insulin sensitivity $\left(S_{\mathrm{I}}\right)$ and glucose effectiveness $\left(S_{\mathrm{G}}\right)$. Interest in the minimal model continues to grow, with more than 50 papers being published each year on issues related to the minimal model. ${ }^{2}$

The original "MINMOD" computer program was developed to specifically carry out the necessary calculations to estimate the parameters of the minimal model. ${ }^{3}$ Parameter estimates determined using MINMOD software have been shown to be highly concordant with analogous parameters estimated by means of the euglycemic clamp. ${ }^{4,5}$ Extant MINMOD software has been used to analyze the data from many

\footnotetext{
${ }^{1}$ School of Veterinary Medicine, University of Pennsylvania, Kennett Square, Pennsylvania.

${ }^{2}$ Clinical Endocrinology Branch, National Institute of Diabetes and Digestive and Kidney Diseases, National Institutes of Health, Bethesda, Maryland.

${ }^{3}$ Department of Preventive Medicine, ${ }^{4}$ Keck School of Medicine, University of Southern California, Los Angeles, California.
} 
hundreds of experiments including thousands of patients and has become, in effect, the "industry standard" for analyzing frequently sampled intravenous glucose tolerance test (FSIGT) data. $^{2}$

The parameters of the minimal model are determined using data from either a standard or modified FSIGT. In the standard FSIGT a bolus of glucose $(300 \mathrm{mg} / \mathrm{kg})$ is intravenously injected, and blood samples are collected over the $3 \mathrm{~h}$ following the glucose injection. In the modified FSIGT $20 \mathrm{~min}$ after the glucose injection, insulin $(30 \mathrm{mU} / \mathrm{kg})$ is infused. ${ }^{6}$ The modified protocol is now almost always used because it allows better estimation of the $S_{\text {I }}$ index. ${ }^{6}$ As well as enabling the estimation of $S_{\mathrm{I}}$ and $S_{\mathrm{G}}$, the minimal model also enables the estimation of a number of other parameters, functions, and indices that are useful for describing the glucose and insulin status of a subject. ${ }^{1,3,7-12}$ These include: the basal glucose concentration $\left(G_{b}\right)$; the basal insulin concentration $\left(I_{b}\right)$; a function that describes insulin action in proportion to interstitial insulin $[X(t)]$; a parameter that describes the removal rate of insulin from the interstitial space $(P 2)$; a parameter that describes the movement of circulating insulin to the interstitial space $(P 3)$; the acute insulin response to glucose $\left(A I R_{\mathrm{g}}\right)$; the disposition index $(D I)$; glucose effectiveness at zero insulin (GEZI); insulin-attributable glucose disposal (IAGD); and two indices derived from the so-called homeostatic assessment (HOMA) model, HOMA $\beta$ cell function and HOMA insulin resistance. The units and typical "normal" values and normal ranges of all of these parameters are shown in Table 1. The mathematical theory and calculations underpinning the minimal model have been discussed previously. ${ }^{1-3}$ The Appendix provides an exposition of the minimal model together with the derivation and explanation of the above parameters and indices.

MINMOD1 was written in FORTRAN 77 and designed to run on a DOS platform. While MINMOD 1 was, in most cases, very accurate with respect to parameter estimates, for perhaps in as many as $15 \%$ of cases, parameter estimates were not identified. In an attempt to fit these recalcitrant cases, users tended to subjectively "experiment" with the weighting of individual data points, and consequently they sometimes obtained, for specific cases, parameter estimates quite different from those obtained by another user analyzing the same data. In addition, alternative FSIGT protocols were introduced to reduce difficult cases. ${ }^{6-8}$

Improvements were made to the computational algorithms underpinning MINMOD, and versions II and III were released. Some of the computational changes that have been introduced into MINMOD may, prima facie, seem subtle if not trivial, but, nevertheless,

Table 1. Glucose Minimal Model Indices, Their Units, and Typical Normal Values and Normal Ranges

\begin{tabular}{|c|c|c|c|c|}
\hline \multicolumn{2}{|l|}{ Clinical index } & \multirow[b]{2}{*}{ Unit } & \multicolumn{2}{|c|}{ Typical normal } \\
\hline Name & Abbreviation & & Value & Range \\
\hline Glucose effectiveness & $S_{\mathrm{G}}$ & $\min ^{-1}$ & $2.2 \mathrm{e}-2$ & $(1.2 \mathrm{e}-3,4.5 \mathrm{e}-2)$ \\
\hline Insulin sensitivity & $S_{\mathrm{I}}$ & $(\mathrm{mU} / \mathrm{L})^{-1} \mathrm{~min}^{-1}$ & $2.0 \mathrm{e}-4$ & $(5.0 \mathrm{e}-5,2.2 \mathrm{e}-3)$ \\
\hline & $P 2$ & $\min ^{-1}$ & $5.0 \mathrm{e}-2$ & $(1.3 \mathrm{e}-3,2.0 \mathrm{e}-1)$ \\
\hline & $P 3$ & $(\mathrm{mU} / \mathrm{L}) \mathrm{min}^{-2}$ & $2.1 \mathrm{e}-5$ & $(5.4 \mathrm{e}-7,8.0 \mathrm{e}-5)$ \\
\hline Basal glucose & $G_{\mathrm{b}}$ & $\operatorname{mg~dL^{-1}}$ & 84 & $(65,103)$ \\
\hline Distributed glucose concentration at time 0 & $G_{0}$ & $\operatorname{mg~dL} L^{-1}$ & 200 & $(150,400)$ \\
\hline Basal insulin & $I_{\mathrm{b}}$ & $\mathrm{mU} \mathrm{L}^{-1}$ & 10 & $(1,32)$ \\
\hline Acute insulin response to glucose & $A I R_{\mathrm{g}}$ & $\mathrm{mU} \mathrm{L}^{-1} \min ^{-1}$ & 800 & $(45,3700)$ \\
\hline Disposition index & $D I^{5}$ & & $8.0 \mathrm{e}-2$ & $(1.6 \mathrm{e}-2,1.0)$ \\
\hline Glucose effectiveness at zero insulin & GEZI & $\min ^{-1}$ & $1.8 \mathrm{e}-2$ & (NA) \\
\hline Insulin-attributable glucose disposal & $I A G D$ & $\%$ & 10 & $(0,90)$ \\
\hline$\beta$-Cell function & $\beta$-Cell function & $\mathrm{mU} / \mathrm{m} M$ & 170 & $(30,1,440)$ \\
\hline Insulin resistance & & $\mathrm{m} M \mathrm{mU} \mathrm{L}^{-2}$ & 2.0 & $(0.4,8)$ \\
\hline Insulin action & $X$ & $\min ^{-1}$ & 0.01 & $(0,0.03)$ \\
\hline Apparent volume of glucose distribution & $V_{\mathrm{g}}$ & $\mathrm{dL}$ & 140 & $(30,292)$ \\
\hline
\end{tabular}

NA, not applicable. 
many of these changes significantly improved the ability of MINMOD software to converge on feasible solutions of the minimal model with identified parameter estimates. However, to date, no publications have critically compared the several versions of MINMOD. Furthermore, with the advent of the Windows operating system and the gradual phasing-out of DOS systems, there has been a growing need for a replacement program that would incorporate all of the latest improvements in MINMOD software into a program with standard Windows features. To attempt to satisfy this need we have introduced an entirely new version of MINMOD that incorporates features of Windows, and that is designed to automatically deliver accurate and precise estimates of $S_{\mathrm{G}}$ and $S_{\text {I }}$. This new version, entitled MINMOD Millennium ${ }^{\mathrm{TM}}$, is described herein.

\section{DESIGN CONSIDERATIONS}

Before we embarked on the development of MINMOD Millennium, a panel of MINMOD III users was asked to identify design issues they would like to see incorporated into MINMOD Millennium. Although the panel identified over 20 desirable design attributes (see Table 2 ), they considered the following as most important: be Windows-based, have a simple interface, and be automatic, accurate, repeatable, reproducible, and concordant with prior versions of MINMOD. In order to meet these design considerations we have focused on three main areas: (1) improved automatic estimation of initial values of parameters; (2) an improved baseline correction algorithm; and (3) a highly robust and accurate numerical integrator.

\section{MATERIALS AND METHODS}

\section{Program development}

Optimization of the estimates of the parameters of the minimal model necessitates some sophisticated mathematical procedures. ${ }^{3}$ Rather than developing new computer code to carry out these procedures, we chose to utilize in Millennium the new processing kernel in the
Table 2. Desirable Design Attributes of MINMOD MiLlenNium

- Windows-compatible

- Simple and powerful data editor for data entry and correction

- Consistent and sensible statistical weighting of observations

- Manual data weighting for difficult cases

- Automatic initialization of all estimable parameters

- Automatic and flexible baseline estimation

- Minimal user intervention to produce Minimal Model parameters

- Proven/published estimation and model solution strategies

- Execution time less than $4 \mathrm{~s}$ per subject

- Reliable, precise, and efficient

- Accurate, repeatable, and reproducible

- Rigorous testing prior to release

- All Minimal Model determinations and their uncertainties automatically tabulated

- Tabulation of predicted values of glucose and insulin action

- Exportation of results between productivity and statistical packages

- Results concordant with prior versions of MINMOD to better than $90 \%$

- Conservation of prior MINMOD method to simulate interstitial insulin inputs

- Able to process all past MINMOD input files

- A comprehensive help system

SAAM (Simulation, Analysis and Modeling) program. ${ }^{13,14}$

The most important part of the development process involved devising an expert system that would enable the program to automatically obtain "best fits" of the minimal model to FSIGT data. The principal features of the expert system were: (a) the automatic estimation of good initial estimates of $S_{\mathrm{G}}, G_{0}$, and $G_{\mathrm{b}}$; (b) the capability to convert Millennium files into files that can be analyzed by the SAAM processing kernel; and (c) the capability to instruct the SAAM processing kernel to progressively adjust the data weighting during the iterative estimation process.

\section{Estimation of initial values of parameters}

In order for MINMOD Millennium to optimize the parameters describing the nonlinear differential equations of the minimal model, the program requires initial estimates for each of the adjustable parameters. ${ }^{3}$ We considered a number of approaches for obtaining initial es- 
timates for parameters $S_{\mathrm{G}}, G_{0}, P 2$, and $P 3$. However, after much experimentation, the procedure that we finally chose for our initial estimation of $S_{\mathrm{G}}$ involved a linear regression of log-transformed glucose data between 8 and 20 min, followed by identification of a possible outlier datum. A robust regression was then conducted on the 8-20-min data excluding any identified outlier datum. Our initial estimate of $G_{0}$ was then taken as the antilog of the time 0 intercept of this robust regression, and our initial estimation of $S_{\mathrm{G}}$ was taken to be the regression coefficient. We used values of 0.0506 and 0.0000211 as our initial estimates of $P 2$ and $P 3$, respectively, as these values are consistent with typical values determined for a human population. ${ }^{15}$ This is equivalent of having a value of $4.15 \times 10^{-4}$ as our initial estimate for $S_{\mathrm{I}}$.

\section{Baseline correction}

In the past, minimal model parameter identification was plagued by estimation problems, especially for subjects with inadequate insulin response. ${ }^{6}$ For example, failure rates of $4-61 \%$ for the fitting procedure for the glucose-only FSIGT data have been reported. ${ }^{16,17}$ In these situations, the assignment of an appropriate $G_{b}$ has been shown to greatly improve the success rate for obtaining identified parameters. ${ }^{16}$ In the original MINMOD paper, stationarity was presumed, such that the value of glucose at the end of the test was presumed to be $G_{b}$, the preinjection glucose concentration. ${ }^{3}$ In practice, however, the plasma glucose concentration may not return to the exact original pre-injection glucose concentration. Nevertheless, we found it was necessary to address the "changing baseline" phenomenon to produce acceptable results describing the glucose profile.

In MINMOD Millennium, we have addressed this "baseline stationarity" problem by completely automating the procedure for estimating the target "baseline" glucose as follows: (a) If the data file contains a datum at $180 \mathrm{~min}$, and this datum exceeds the pre-injection glucose value, we assign the target glucose to be approached at the end of the test $(t=180 \mathrm{~min})$ to the average of the pre-injection value of glucose and the measured value for glucose at time $180 \mathrm{~min}$. (b) If there is no glucose datum at 180

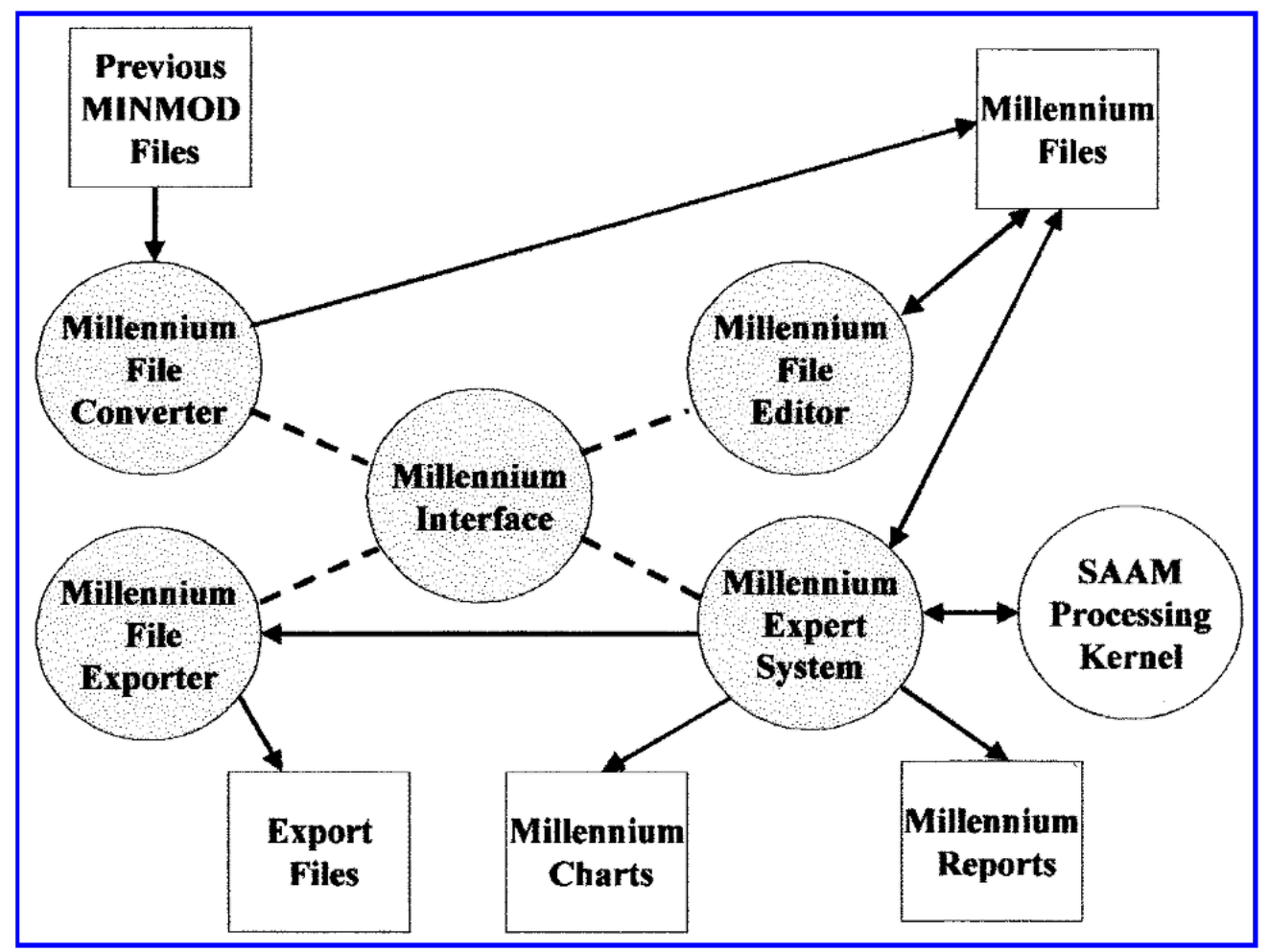

FIG. 1. The structure and functioning of MINMOD Millennium. The gray circles represent the five main parts of MINMOD Millennium, and the dashed lines depict how the interface controls the activities of the other parts. The solid lines represent the pathways for the movement of data through MINMOD Millennium. 
min, but data after $180 \mathrm{~min}$ and data between 120 and $179 \mathrm{~min}$, then we take the average of the closest datum points on either side of 180 min, and we assign to $G_{\mathrm{b}}$ the average of this value and the pre-injection value of glucose. (c) If we have data with time values greater than $119 \mathrm{~min}$ but no data greater than $180 \mathrm{~min}$, then the program assigns the mean of the glucose value of the datum closest to time $180 \mathrm{~min}$ and the pre-injection glucose value. (d) If we only have data with time values less than $120 \mathrm{~min}$, then $G_{b}$ is assigned the pre-injection glucose value.

There are a number of other ways that we might have addressed the issue of changing baseline, and this issue per se has been discussed in detail in the scientific literature. ${ }^{16}$ However, we chose as the default option the baseline correction algorithm described above in order to ensure concordance of results obtained from Millennium with results obtained by using previous versions of MINMOD software.

\section{RESULTS}

\section{Program description}

MINMOD Millennium is written in Visual Basic, designed to run on any PC with a Windows 98 or higher platform, and to have the appearance and general operating features of Windows-based programs. There are five main parts to Millennium: an interface, an input file editor, a file converter, an expert system linked to a SAAM processing kernel, and a file exporter. Figure 1 depicts how the interface controls the other parts of Millennium and how data are handled within Millennium. The Millennium interface has 10 simple elements (Fig. 2). These include the folder Navigator, the file picker, and eight control buttons. Simply put, the Navigator allows you to locate a folder (directory) containing the dataset you want to process. The File Picker allows you to select the actual dataset (file) to process. The Control Buttons allow you to access the help system, to view the "flash screen," to exit Millennium, or

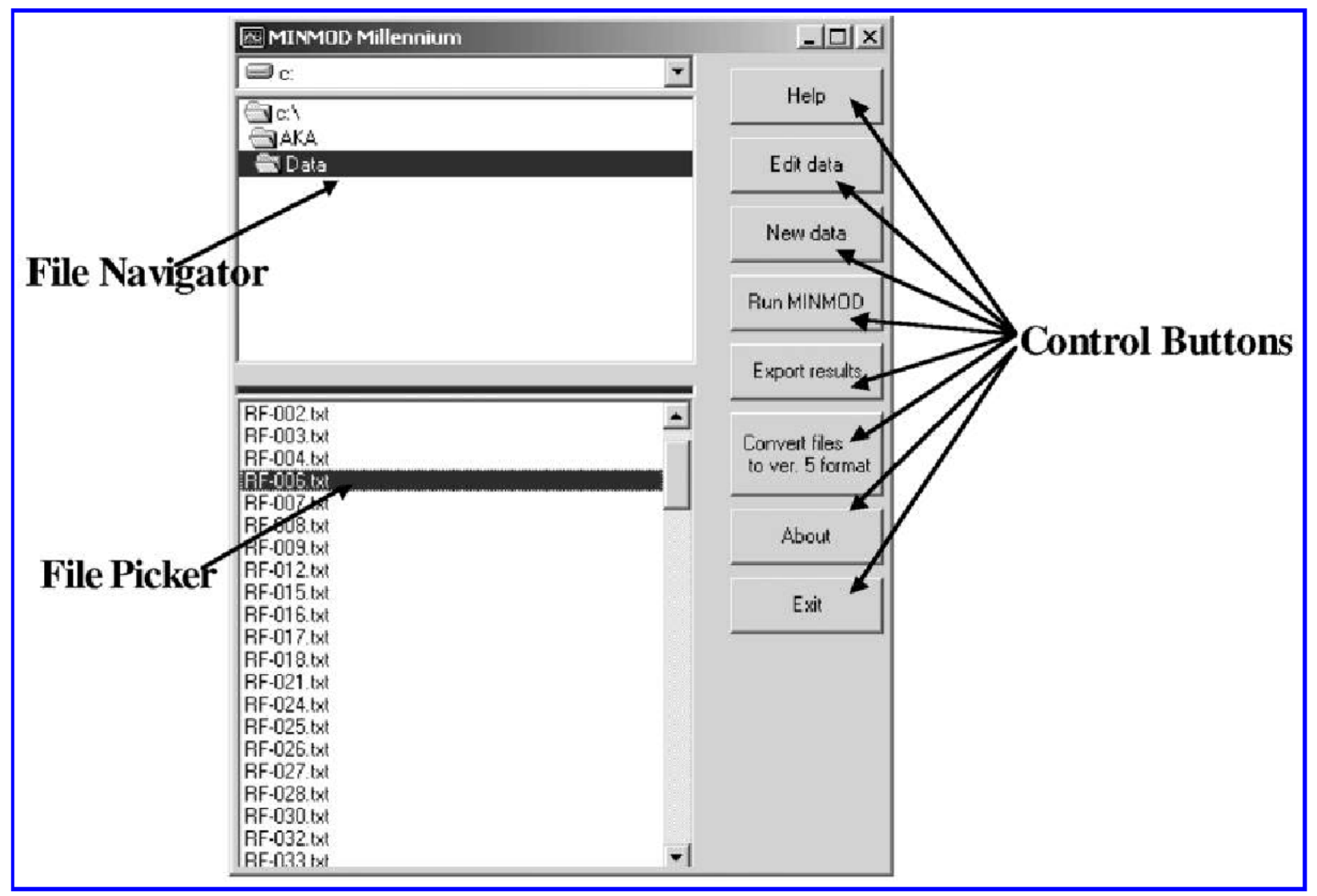

FIG. 2. The MINMOD Millennium interface. 
to select what you want to do with (how you want to process) a selected file. The Millennium user simply uses a mouse to click on the appropriate button to perform the selected task or processing step. For example, by clicking on the HELP button, the user is presented with a dropdown menu of the following items: (1) a brief overview of MINMOD Millennium; (2)

\begin{tabular}{|c|c|c|c|c|}
\hline \multicolumn{3}{|c|}{ Date Editor New data demo } & \multicolumn{2}{|r|}{$x$} \\
\hline File Edit In & sert & & & \\
\hline Time & Glucose & Insulin & Weight & \\
\hline$\overline{0}$ & & & 0 & \\
\hline 1 & & & 0 & \\
\hline 2 & & & 0 & \\
\hline 3 & & & 0 & \\
\hline 4 & & & 0 & \\
\hline 5 & & & 0 & \\
\hline 6 & & & 0 & \\
\hline 7 & & & 0 & \\
\hline 8 & & & 1 & \\
\hline 10 & & & 1 & \\
\hline 12 & & & 1 & \\
\hline 14 & & & 1 & \\
\hline 16 & & & 1 & \\
\hline 18 & & & 1 & \\
\hline 20 & & & 1 & \\
\hline 22 & & & 1 & \\
\hline 24 & & & 1 & \\
\hline 26 & & & 1 & \\
\hline 28 & & & 1 & \\
\hline 30 & & & 1 & \\
\hline 40 & & & 1 & \\
\hline 50 & & & 1 & \\
\hline 60 & & & 1 & \\
\hline 70 & & & 1 & \\
\hline 80 & & & 1 & \\
\hline 90 & & & 1 & \\
\hline 100 & & & 1 & \\
\hline 150 & & & 1 & \\
\hline 180 & & & 1 & \\
\hline 210 & & & 1 & \\
\hline 240 & & & 1 & \\
\hline
\end{tabular}

FIG. 3. The Millennium file editor. The file editor starts a new file with the default times for a standard FSIGT, and glucose data from the first $7 \mathrm{~min}$ are given zero weighting. There are four data columns in the data window: Time, Glucose, Insulin, and Data Weight. The "time" column contains the sampling times for a standard FSIGT protocol, and the data weight column contains the recommended or "default" weighting scheme. The glucose and insulin columns contain "." or periods, which signify missing data. New glucose and insulin data can either be entered directly into this window and the file saved, or data can be copied from an Excel spreadsheet and pasted into the Millennium data editor.

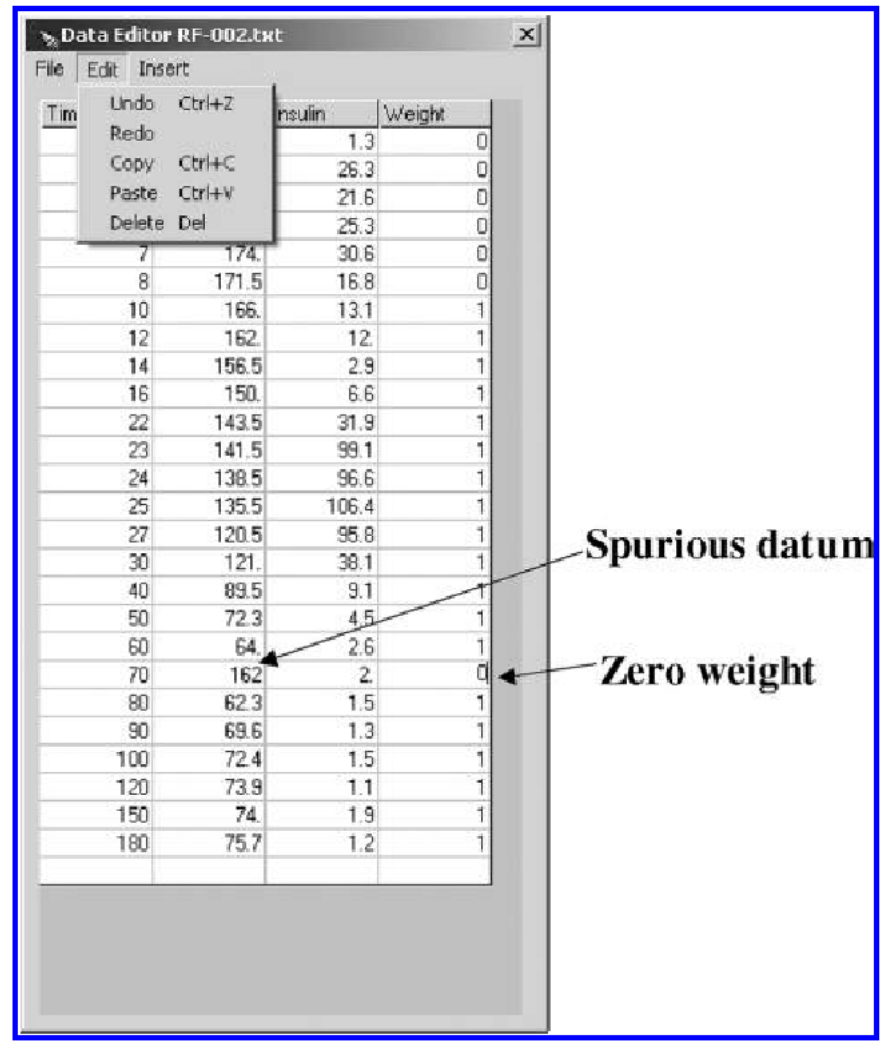

FIG. 4. Editing data. Note that we have activated the "Edit" menu to expose the array of services supported. For example, the user may wish to weight out spurious or unreliable data. To do this, the user changes the " 1 " weighting to " 0 " weighting and saves the amended file. The weights are simply factors that scale the proportional influence of each observation in accord with the weight value assigned. For example, if the weight value assigned for a particular observation is " 2, , then this observation will modify the fit at twice the influence as an identical observation with weight value " 1 ." From the statistical perspective each observation is assigned a constant fractional standard deviation weight, in which the error of an observation is presumed to be proportional to the magnitude of the observation. Weights apply to glucose observations only.

the purpose of MINMOD Millennium; (3) design criteria for MINMOD Millennium; and (4) instructions for using Millennium. The HELP system is quite comprehensive and self-explanatory.

\section{Using MINMOD Millennium}

To carry out a processing step, the Millennium user must click on the appropriate button. Note that no processing action can be taken unless one or more files are selected. However, only one processing step at a time is allowed. The five possible processing steps are: (1) editing the data; (2) entering new data; (3) running 


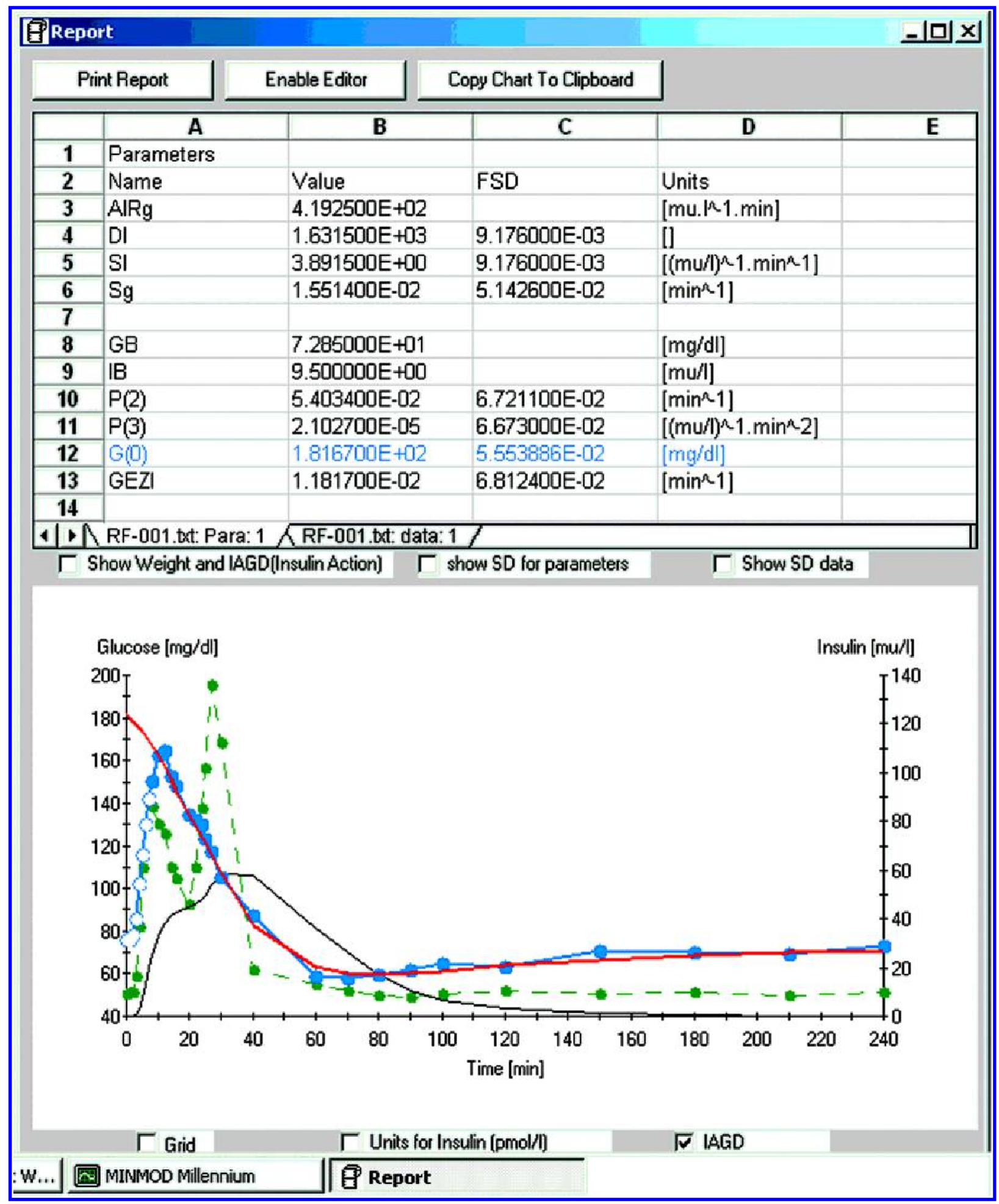

FIG. 5. Millennium report of minimal model parameters and chart of glucose and insulin data, predicted glucose concentrations, and predicted insulin-attributable glucose disposal (IAGD), following a FSIGT. The features of the output parameters window are as follows: All the important parameters estimable from the FSIGT data and the estimates of their uncertainties are summarized. If parameters are not well identified (i.e., their estimated fractional standard deviations are greater than 0.5$)$, then the parameter values and their fractional standard deviations are shown in red. The units of the parameters are provided. Parameters whose values are conditionally estimated (e.g., $\left.G_{0}\right)$ are displayed in blue, along with their uncertainties. The following features of the plot are visible: glucose observations, blue dots; unweighted observations, hollow blue dots; fit of minimal model to glucose observations, red line; insulin observations, green dots (joined with a dashed green line); IAGD, dark solid line. Discontinuous blue and red lines indicate missing glucose data. 
MINMOD; (4) exporting the MINMOD results to a tab-delimited text file; and (5) converting an old MINMOD dataset for processing with MINMOD Millennium.

When a user selects the "New data" button, he/she sees an empty data window as depicted in Figure 3. New glucose and insulin data can be entered directly into the window, and the file is then saved as a Millennium data file with a " $\mathrm{txt}$ " file extension. Alternatively, data can be copied from an Excel file and pasted into the Millennium data file. If it is necessary to make changes to the data file, Millennium has a standard Windows-style editing system. The appropriate data file is highlighted, the "edit data" button is selected, and the data appear in a window similar to that shown in Figure 4. Data files that have been produced by previous versions of MINMOD cannot be run directly in Millennium, but must first be converted to a form that can be used by Millennium. This conversion process is easily achieved by highlighting the file(s) that need to be converted, and then selecting the "Convert files to version 5 format" button.

\section{Analysis of data with MINMOD Millennium}

To fit an FSIGT dataset using MINMOD Millennium, the user simply "picks" the file or files to be processed, and invokes the control button "Run MINMOD." With a modern desktop or laptop computer (cycle speed of $1.2 \mathrm{GHz}$ ) Millennium provides output in approximately $0.75 \mathrm{~s}$ for each dataset. For each dataset analyzed, Millennium produces a report similar to that shown in Figure 5. The parameters window can be directly printed. The results displayed in the parameters window can, by simply clicking on the "Enable editor" button at the top of the parameters window, be loaded into what is known as a designer window (see Fig. 6), and from there, all of the routine spreadsheet services, including exportation, become available. In fact we can accomplish this step using either cut/copy-and-paste operations, or by saving the spreadsheet in the appropriate compatible format.

The plot of the results appears in a plot window accompanying the parameters window (Fig. 5). A grid can be displayed, the units of insulin can be toggled between English and so- called SI units (mU/L vs. pmol/L), and the display of IAGD can also be toggled. The symbols, line styles, fonts, and background colors of the plot window can all be changed to the user's preferences. By clicking on the "Copy chart to clipboard" button, the plot window can be copied and then pasted in Word, PowerPoint, or other Windows-based programs.

While clinicians are interested in minimal model parameters of individual subjects, researchers are likely to have a requirement to analyze FSIGT data from multiple subjects in experimental groups or populations. The export facility in Millennium has been specifically designed to facilitate the rapid analysis of FSIGT data from large numbers of subjects. To carry out a minimal model analysis of FSIGT data from multiple subjects, a Millennium user need simply select the relevant files (using the Navigator and File Picker) and then click on the "Export" button. Millennium will respond with a dropdown menu prompting the user to enter the name of a text file in which the results are to be tabulated. Having entered an appropriate file name, Millennium will then produce a tab-delimited "txt" file containing subject identifier, minimal model parameter estimates, and their fractional standard deviations. Statistical or epidemiological analyses can then be performed on these population data using standard statistical packages such as STATA $^{18}$ or SAS. ${ }^{19}$

\section{TESTING AND VALIDATION}

Data from 131 subjects who had undergone the FSIGT were analyzed by both MINMOD 3 and MINMOD Millennium. Concordance analyses were conducted using the "concord" command in STATA. ${ }^{18}$ Figure 7 shows the concordance relationship and concordance statistics for $S_{\mathrm{G}}$ estimated by MINMOD 3 and by MINMOD Millennium, while Figure 8 shows a similar concordance relationship for $S_{\mathrm{I}} \cdot{ }^{20,21}$ For this particular population, MINMOD Millennium produced identified estimates (fractional standard deviations less than 0.5 ) of $S_{\mathrm{G}}$ and $S_{\mathrm{I}}$ for all 131 subjects. In comparison, MINMOD 3 produced identified estimates of $S_{\mathrm{G}}$ and $S_{\mathrm{I}}$ in 125 and 129 subjects, respectively. When the 


\begin{tabular}{|c|c|c|c|c|c|c|c|c|c|}
\hline \multicolumn{8}{|c|}{ EF Formula One Workbook Designer } & \multicolumn{2}{|c|}{-10 미 } \\
\hline \multicolumn{10}{|c|}{ File Edit View Data sheet Format object Help } \\
\hline \multicolumn{10}{|c|}{ 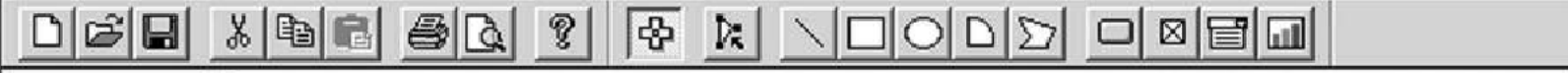 } \\
\hline \multicolumn{10}{|c|}{ A65 } \\
\hline & A & B & C & D & $\mathrm{E}$ & $\mathrm{F}$ & G & H & $\perp$ \\
\hline 1 & \multicolumn{2}{|c|}{ \# of Observations 31} & & & & & & & \\
\hline 2 & Time & Glucose & Calc. Glucose & FSD & Insulin & Weight & IAGD & $\mathrm{x}$ & \\
\hline 3 & 0 & 75.9 & 1.817E+02 & $0.000 E+00$ & 9.5 & 0 & $0.000 E+00$ & \multicolumn{2}{|l|}{$0.000 E+00$} \\
\hline 4 & 1 & 76.2 & $1.800 E+02$ & 4.753E-04 & 9.7 & 0 & $1.331 \mathrm{E}-02$ & \multicolumn{2}{|l|}{ 2.065E-06 } \\
\hline 5 & 2 & 78.2 & $1.783 E+02$ & 9.442E-04 & 9.8 & 0 & 4.564E-02 & \multicolumn{2}{|l|}{$7.083 \mathrm{E}-06$} \\
\hline 6 & 3 & 85.8 & $1.767 E+02$ & 1.405E-03 & 16.4 & 0 & 5.194E-01 & \multicolumn{2}{|l|}{ 8.101E-05 } \\
\hline 7 & 4 & 102.5 & $1.751 E+02$ & 1.849E-03 & 37 & 0 & $2.701 E+00$ & \multicolumn{2}{|l|}{ 4.307E-04 } \\
\hline 8 & 5 & 115.5 & $1.734 E+02$ & 2.254E-03 & 61.3 & 0 & $7.301 E+00$ & \multicolumn{2}{|l|}{$1.222 \mathrm{E}-03$} \\
\hline 9 & 6 & 130 & $1.715 E+02$ & 2.595E-03 & 79.6 & 0 & $1.343 \mathrm{E}+01$ & \multicolumn{2}{|l|}{ 2.407E-03 } \\
\hline 10 & 7 & 142.5 & $1.695 E+02$ & 2.857E-03 & 87.1 & 0 & $1.964 E+01$ & \multicolumn{2}{|l|}{ 3.793E-03 } \\
\hline 11 & 8 & 150.5 & $1.672 E+02$ & 3.041E-03 & 86.4 & 1 & $2.501 \mathrm{E}+01$ & \multicolumn{2}{|l|}{ 5.174E-03 } \\
\hline 12 & 10 & 162.5 & $1.623 \mathrm{E}+02$ & 3.215E-03 & 79 & 1 & $3.276 \mathrm{E}+01$ & \multicolumn{2}{|l|}{$7.560 \mathrm{E}-03$} \\
\hline 13 & 12 & 165 & $1.568 \mathrm{E}+02$ & 3.219E-03 & 75 & 1 & $3.792 \mathrm{E}+01$ & \multicolumn{2}{|l|}{$9.474 \mathrm{E}-03$} \\
\hline 14 & 14 & 152.5 & $1.512 \mathrm{E}+02$ & $3.142 E-03$ & 61.4 & 1 & 4.113E+01 & \multicolumn{2}{|l|}{ 1.084E-02 } \\
\hline 15 & 16 & 148 & $1.455 \mathrm{E}+02$ & 3.066E-03 & 56.6 & 1 & $4.299 E+01$ & \multicolumn{2}{|l|}{$1.170 \mathrm{E}-02$} \\
\hline 16 & 20 & 135 & $1.345 \mathrm{E}+02$ & 3.043E-03 & 46.1 & 1 & 4.477E+01 & \multicolumn{2}{|l|}{$1.258 \mathrm{E}-02$} \\
\hline 17 & 22 & 132.5 & $1.293 \mathrm{E}+02$ & 3.101E-03 & 60.9 & 1 & $4.568 \mathrm{E}+01$ & \multicolumn{2}{|l|}{ 1.305E-02 } \\
\hline 18 & 24 & 130 & $1.242 \mathrm{E}+02$ & 3.168E-03 & 85.4 & 1 & 4.789E+01 & \multicolumn{2}{|l|}{$1.426 \mathrm{E}-02$} \\
\hline 19 & 25 & 123.5 & $1.216 \mathrm{E}+02$ & 3.202E-03 & 101.7 & 1 & $4.954 E+01$ & \multicolumn{2}{|l|}{$1.523 \mathrm{E}-\mathrm{D} 2$} \\
\hline 20 & 27 & 117 & $1.162 \mathrm{E}+02$ & 3.299E-03 & 135.8 & 1 & $5.376 \mathrm{E}+01$ & \multicolumn{2}{|l|}{$1.804 \mathrm{E}-\mathrm{02}$} \\
\hline 21 & 30 & 105.5 & 1.076E +02 & 3.768E-03 & 112.2 & 1 & $5.863 E+01$ & \multicolumn{2}{|l|}{ 2.199E-02 } \\
\hline 22 & 40 & 87 & $8.246 E+01$ & 7.079E-03 & 18.9 & 1 & $5.778 E+01$ & $2.123 \mathrm{E}-02$ & \\
\hline \multicolumn{8}{|c|}{ 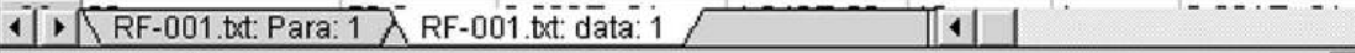 } & \\
\hline \multicolumn{8}{|c|}{ For Help, press F1 } & & \#̈. \\
\hline
\end{tabular}

FIG. 6. MINMOD Millennium output spreadsheet.

same user repeatedly analyzed the above data, identical parameter estimates were obtained for the same subjects. Furthermore, identical parameter estimates were also obtained when the same data were analyzed by a different user employing a different computer. The robustness of Millennium is evident from the fact that when it was used to analyze data from $30 \mathrm{sub}$ jects that had undergone the original FSIGT protocol (no insulin injection) it was able to produce identified parameters for 29 of the subjects.

In comparison with MINMOD 3, an outstanding attribute of Millennium is the ease and quickness with which it allows the analysis of large numbers of FSIGT cases and the exportation of the results of the analyses to other productivity programs for statistical analysis. Using a Fujitsu (C Series Lifebook) and Mil- lennium, we have analyzed the above 130 FSIGT studies, exported the results to a " $\mathrm{txt}$ " file, and then, using STATA, made population estimates of each of the minimal model parameters in less than $4 \mathrm{~min}$ ! Using MINMOD 3 to do this would have required several hours.

\section{CONCLUSIONS}

It is a truism that obesity and Type 2 diabetes are reaching epidemic proportions in Westernized populations, including the United States, and rates are increasing alarmingly in developing nations. ${ }^{22}$ However, pharmacological and lifestyle approaches to prevention have been demonstrated. ${ }^{23,24}$ Recently, it has become possible to predict with some degree of confidence (long before the disease is evident) those 


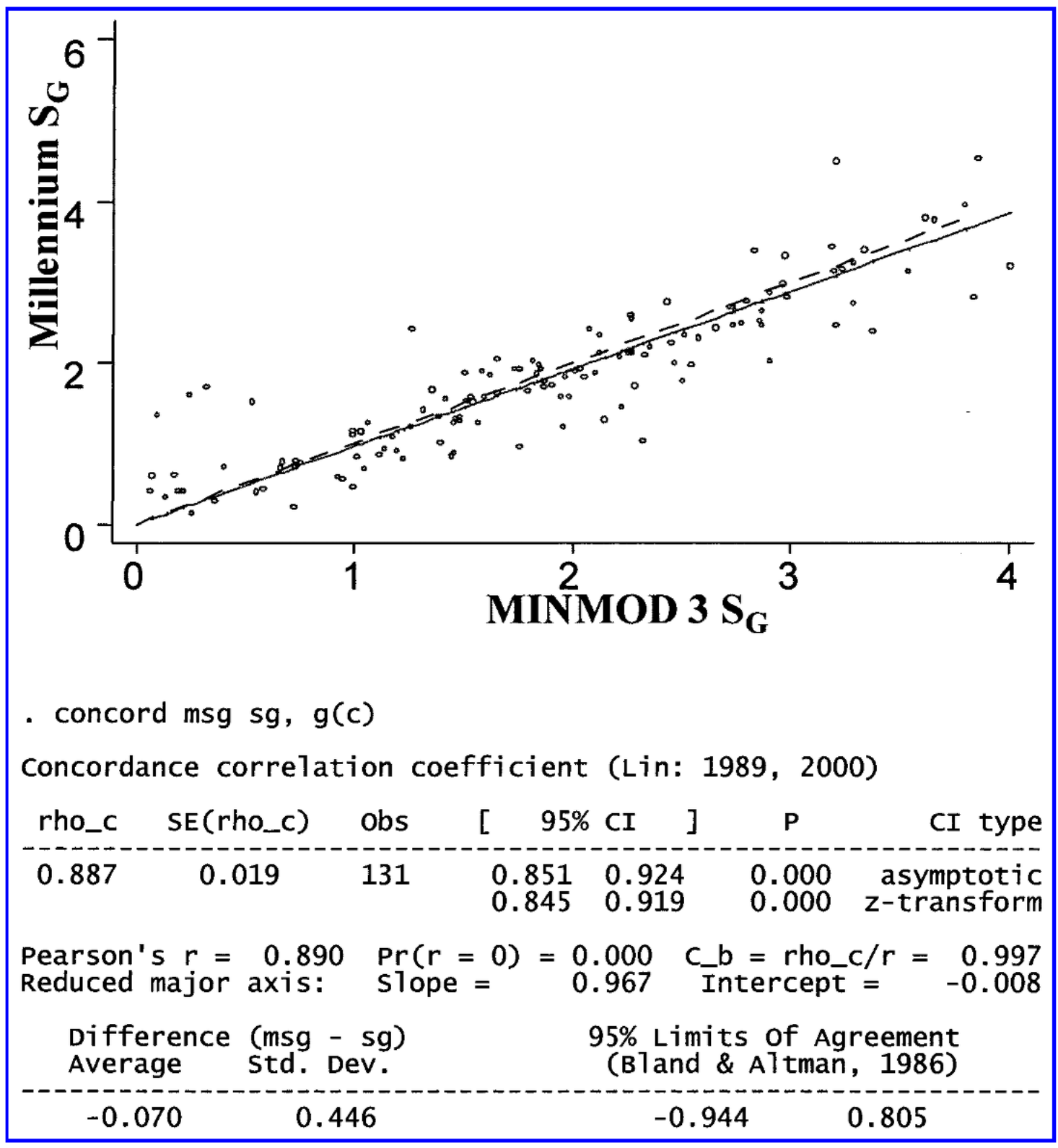

FIG. 7. A graph showing the high degree of concordance between $S_{\mathrm{G}}$ as determined by MINMOD Millennium and $S_{\mathrm{G}}$ as determined by MINMOD 3. Note that data must overlay the dashed line for perfect concordance. Concordance parameters were obtained by using STATA ${ }^{18}$ to analyze the $S_{\mathrm{G}}$ estimates from 131 FSIGT data sets. The concordance correlation coefficient was calculated according to Lin, ${ }^{20}$ and the $95 \%$ limits of agreement according to Bland and Altman. ${ }^{21}$

subjects likely to develop Type 2 diabetes. It is important to identify those individuals at greatest risk for the disease. A reduced DI is predictive of Type 2 diabetes. To accurately estimate $D I$ one must assess $S_{\mathrm{I}}$ and $A I R_{\mathrm{g}}$. This can be done accurately with the present program. MINMOD Millennium is a Windows-based version of minimal model software for the quantitative assessment of the glucose/insulin dynamics of individual subjects. Extensive beta testing of MINMOD Millennium has shown that it is indeed user-friendly, fully automatic, robust, fast, accurate, reproducible, repeatable, and highly concordant with past versions of MINMOD. It has a simple interface, a comprehensive help system, an input file editor, a file converter, an intelligent processing kernel, and a file exporter, and it provides publicationquality charts of glucose and insulin and a table of all minimal model parameters and their error estimates. In contrast to earlier versions of MINMOD and some other minimal model pro- 


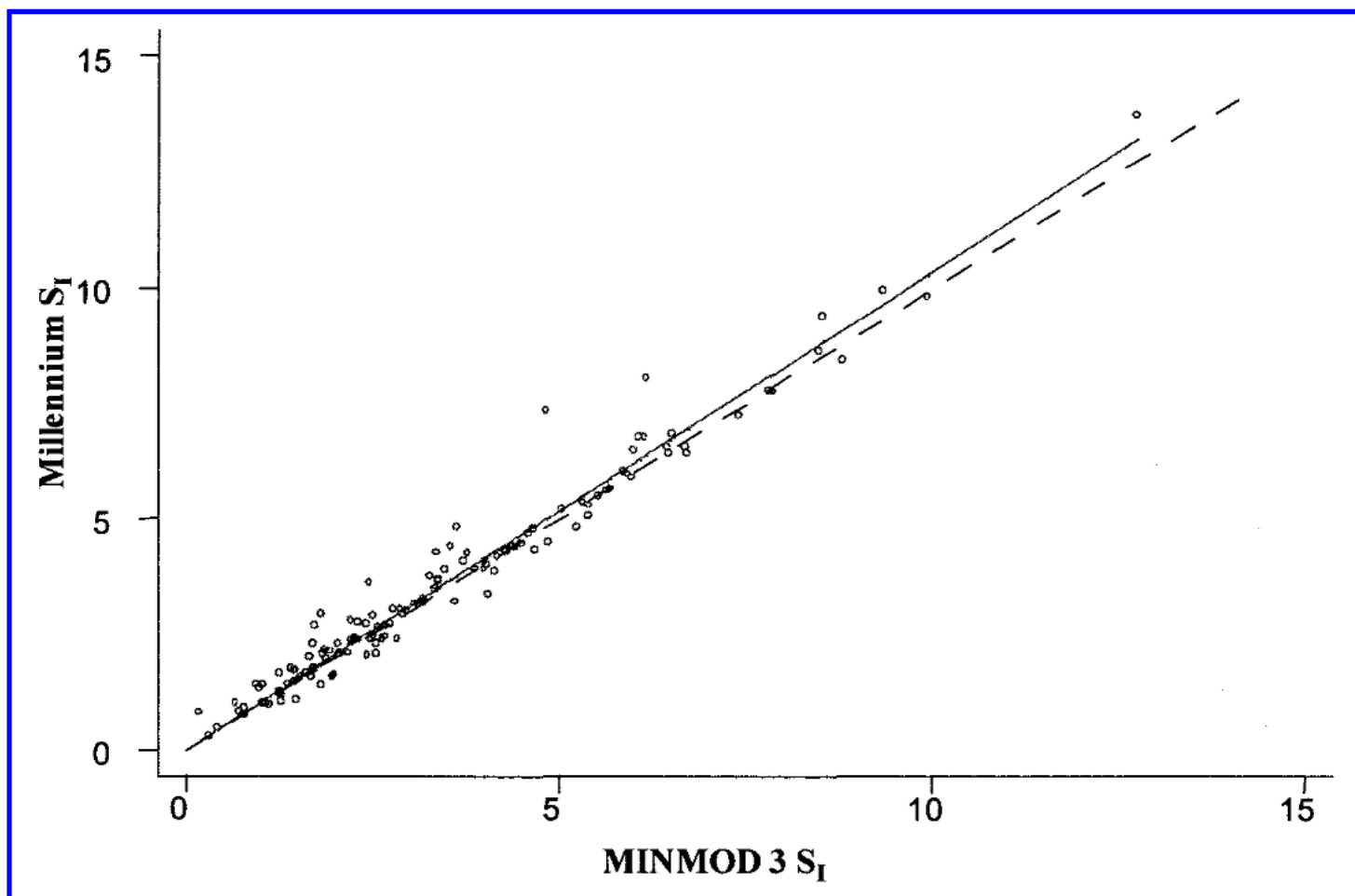

- concord msi si, g(c)

Concordance correlation coefficient (Lin: 1989, 2000)

\begin{tabular}{|c|c|c|c|c|c|c|}
\hline rho_c & SE (rho_c) & obs & $95 \%$ & $C I$ & $\mathbf{P}$ & CI type \\
\hline 0.981 & 0.003 & 131 & $\begin{array}{l}0.974 \\
0.973\end{array}$ & $\begin{array}{l}0.987 \\
0.986\end{array}$ & $\begin{array}{l}0.000 \\
0.000\end{array}$ & $\begin{array}{l}\text { asymptoti } \\
z \text {-transfor }\end{array}$ \\
\hline
\end{tabular}

\begin{tabular}{|c|c|c|c|c|c|}
\hline $\begin{array}{l}\text { Pearson's } r= \\
\text { Reduced major }\end{array}$ & $\begin{array}{l}0.983 \\
\text { axis: }\end{array}$ & $\begin{array}{l}\operatorname{Pr}(r=0)= \\
\text { slope }=\end{array}$ & $\begin{aligned}= & 0.000 \\
& 1.037\end{aligned}$ & 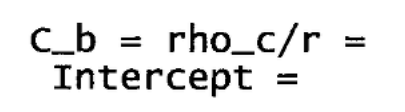 & $\begin{array}{l}0.998 \\
0.003\end{array}$ \\
\hline $\begin{array}{l}\text { Difference } \\
\text { Average }\end{array}$ & $\begin{array}{l}\text { (msi - } \\
\text { Std. De }\end{array}$ & $\begin{array}{l}\text { si) } \\
\text { v. }\end{array}$ & $\begin{array}{l}95 \% \text { L } \\
\text { (B } 7 \mathrm{a}\end{array}$ & $\begin{array}{l}\text { imits of Agreement } \\
\text { ind \& A7tman, 1986) }\end{array}$ & \\
\hline 0.129 & 0.43 & & & 0.721 & \\
\hline
\end{tabular}

FIG. 8. A graph showing the high degree of concordance between $S_{\mathrm{I}}$ as determined by MINMOD Millennium and $S_{\mathrm{I}}$ as determined by MINMOD 3. Note that data must overlay the dashed line for perfect concordance. Concordance parameters were obtained by using STATA ${ }^{18}$ to analyze the $S_{\text {I }}$ estimates from 131 FSIGT data sets. The concordance correlation coefficient was calculated according to $\mathrm{Lin}_{,}{ }^{20}$ and the $95 \%$ limits of agreement according to Bland and Altman. ${ }^{21}$

grams, Millennium provides identified estimates of $S_{\mathrm{I}}$ and $S_{\mathrm{G}}$ for almost every subject. It is hoped that the availability of this software may contribute to prevention of diabetes in atrisk individuals.

\section{APPENDIX}

Bergman's approach to describe the complex interaction of glucose and insulin involves two differential equations:

$$
\begin{gathered}
\frac{d G(t)}{d t}=-G(t) \times\left[S_{G}+X(t)\right] \\
\quad+G_{\mathrm{b}} \times S_{G} G(0)=G_{0} \\
\frac{d X(t)}{d t}=-P 2 \times X(t)+P 3 \times F(t) X(0)=0 \\
F(t)=0 \text { if } I(t) \leq I_{\mathrm{b}}, \text { else } I(t)-I_{\mathrm{b}} \\
S_{\mathrm{I}}=P 3 / P 2
\end{gathered}
$$

where $S_{\mathrm{G}}$ is glucose effectiveness; $S_{\mathrm{I}}$ is insulin sensitivity; $G(t)$ is plasma glucose at time $t ; G_{\mathrm{b}}$ is the basal glucose concentration; $I(t)$ is the 
plasma insulin concentration at time $t ; I_{\mathrm{b}}$ is the basal insulin concentration; $F(t)$ is a function that represents the elevation of plasma insulin above basal insulin; $X(t)$ is insulin action in proportion to interstitial insulin ${ }^{1,3,9}$; P2 is a parameter describing the removal rate of insulin from the interstitial space; and $P 3$ is a parameter describing the movement of circulating insulin to the interstitial space. The two main indices of the minimal model are $S_{\mathrm{G}}$ and $S_{\mathrm{I}}$. $S_{\mathrm{G}}$ indicates the capacity of glucose to mediate its own disposal, whereas $S_{\text {I }}$ indicates the net capacity for insulin to promote the disposal of glucose and to inhibit the endogenous production of glucose. In addition to these, a number of other useful indices can be derived from the FSIGT and minimal model. The acute insulin response to glucose $\left(A I R_{\mathrm{g}}\right)$ represents the acute insulin response and is defined as the area under the plasma insulin curve between 0 and $10 \mathrm{~min}$ :

$$
A I R_{\mathrm{g}}=\int_{0}^{10}\left[I(t)-I_{\mathrm{b}}\right] d t
$$

The disposition index DI is an overall measure of the ability of the islet cells to secrete insulin normalized to the degree of insulin resistance. $D I$ is the product of $A I R_{\mathrm{g}}$ and $S_{\mathrm{I}}$ :

$$
D I=A I R_{\mathrm{g}} \times S_{\mathrm{I}}
$$

GEZI (glucose effectiveness at zero insulin), which is an index popularized by Araujo-Vilar et al., ${ }^{10}$ is a measure of $S_{\mathrm{G}}$ that is independent of incremental insulin. It is defined as follows:

$$
G E Z I=S_{\mathrm{G}}-S_{\mathrm{I}} \times I_{\mathrm{b}}
$$

A useful time-varying descriptor is IAGD (insulin-attributable glucose disposal), viz.:

$$
I A G D=100 \times X /\left(X+S_{\mathrm{G}}\right)
$$

This reflects the instantaneous percentage of glucose disposal attributable to the action of interstitial insulin, as opposed to the action of glucose per se.

$V_{\mathrm{g}}$ (apparent distribution space of glucose) is the extracellular fluid space in which glucose appears to distribute, and is estimated by:

$$
V_{\mathrm{g}}=300 \times B W / G_{0}
$$

where $B W$ is the body weight in $\mathrm{kg}$.

\section{"HOMA" parameters}

Two indices proposed by Mathews et al. ${ }^{12}$ from the so-called HOMA model are $\beta$-cell function and insulin resistance. These parameters are defined as follows:

HOMA $\beta$-cell function

$$
=20 \times I_{\mathrm{b}} /\left(G_{\mathrm{b}} / 18-3.5\right)
$$

HOMA insulin resistance $=G_{\mathrm{b}} \times I_{\mathrm{b}} / 405$

Solving the nonlinear differential equations involved in the Bergman glucose minimal model involves some formidable matrix algebra. Furthermore, since glucose and insulin are co-regulating, the relatively strong correlation between plasma glucose and insulin that may occur in some subjects has resulted in some minimal model programs being able to estimate identified parameters in only about $85 \%$ of cases. ${ }^{16}$ In the original glucose minimal model (Eqs. 2 and 3), Bergman used the actual insulin data (interpolated by straight lines) to represent $I(t)$, thereby uncoupling the glucose model from the insulin model. This wisely obviated the need for the simultaneous determination of the parameters of both the glucose model and the insulin model, and this approach is maintained in MINMOD Millennium.

\section{ACKNOWLEDGMENTS}

We wish to thank: Marilyn Ader for providing data that were helpful for testing and validating MINMOD Millennium; Peter Grief for his role in developing the SAAM computer program, which is used in the processing kernel of MINMOD Millennium; and Oscar Linares and David Nunamaker for their encouragement and financial support. R.N.B. is supported by the National Institutes of Health (grants DK27619 and DK29867).

\section{REFERENCES}

1. Bergman RN, Ider ZY, Bowden CR, Cobelli C: Quantitative estimation of insulin sensitivity. Am I Physiol 1979;236:E667-E677.

2. Finegood DT: Application of the minimal model of glucose kinetics. In: Bergman RN, Lovejoy JC, eds. 
The Minimal Model Approach and Determinants of Glucose Tolerance. Baton Rouge: Louisiana State University Press, 1997:51-122.

3. Pacini G, Bergman RN: MINMOD: a computer program to calculate insulin sensitivity and pancreatic responsivity from the frequently sampled intravenous glucose tolerance test. Comput Methods Programs Biomed 1986;23:113-122.

4. Saad MF, Anderson RL, Laws A, Watanabe RM, Kades WW, Chen Y-D, Sands E, Pei D, Savage PJ, Bergman RN: A comparison between the minimal model and glucose clamp in the assessment of insulin sensitivity across the spectrum of glucose tolerance. Diabetes 1994;43:114-122.

5. Finegood DT, Pacini G, Bergman RN: The insulin sensitivity index: correlation in dogs between values determined from the intravenous glucose tolerance test and the euglycemic clamp. Diabetes 1984;33:362-368.

6. Yang Y, Youn J, Bergman RN: Modified protocols improve insulin sensitivity estimation using the minimal model. Am I Physiol 1987;253:E595-E602.

7. Dunaif A, Finegood DT: $\beta$-Cell dysfunction independent of obesity and glucose intolerance in the polycystic ovary syndrome. I Clin Endocrinol Metab 1996;81:942-947.

8. Korytkowski MT, Berga SL, Horwitz MJ: Comparison of the minimal model and the hyperglycemic clamp for measuring insulin sensitivity and acute insulin response to glucose. Metabolism 1995;44:1121-1125.

9. Ader M, Ni TC, Bergman RN: Glucose effectiveness assessed under dynamic and steady state conditions: comparability of uptake versus production components. I Clin Invest 1997;99:1187-1199.

10. Araujo-Vilar D, Rega-Liste C, Garcia-Estevez D, Sarmiento-Escalona F, Mosquera-Tallon V, CabezzaCerrato J: Minimal model of glucose metabolism: modified equations and its application in the study of insulin sensitivity in obese subjects. Diabetes Res Clin Pract 1998;39:129-141.

11. Godsland IF, Felton C, Wynn V: Venous blood arterialization and parameters from the minimal models of glucose disappearance and post hepatic insulin delivery. Clin Sci 1993;85:89-95.

12. Matthews DR, Hosker JP, Rudenski AS, Naylor BA, Treacher DF, Turner RC: Homeostasis model assessment: insulin resistance and $\beta$-cell function from fasting plasma glucose and insulin concentrations in man. Diabetalogia 1985;28:412-419.

13. Berman M, Weiss MF: The SAAM Manual. USPHS (NIH) Publication. Washington, DC: U.S. Government Printing Office, 1978:78-180.
14. Stefanovski D, Moate PJ, Boston RC: WinSAAM: a Windows-based compartmental modeling system. Metabolism 2003;52:1153-1166.

15. Kahn SE, Prigeon RL, McCulloch DK, Boyko EJ, Bergman RN, Schwartz MW, Neifing JL, Ward WK, Beard JC, Palmer JP, Porter D: The contribution of insulin-dependent and insulin-independent glucoseuptake to intravenous glucose-tolerance in healthyhuman subjects. Diabetes 1994;43:587-592.

16. Godsland IF, Walton C: Maximizing the success rate of minimal model insulin sensitivity measurement in humans: the importance of basal glucose levels. $\underline{\text { Clin }}$ Sci 2001;101:1-9.

17. Mehring GH, Coates PA, Brunel PC, Luzio SD, Owens DR: Insulin sensitivity in Type 2 diabetes: univariate and multivariate techniques to derive estimates of insulin sensitivity from the insulin modified intravenous glucose tolerance test (FSIGT). Comput Methods Programs Biomed 2002;68:161-176.

18. Stata Corp.: Stata Statistical Software: Release 7.0. College Station, TX: Stata Corp., 2001.

19. SAS User's Guide: Statistics, Version 5. Cary, NC: SAS Institute, 1985.

20. Lin LI-K: A concordance correlation coefficient to evaluate reproducibility. Biometrics 1989;45:255-268.

21. Bland JM, Altman DG: Statistical methods for assessing agreement between two methods of clinical measurement. Lancet 1986;1:307-310.

22. Zimmet $P$, Alberti KG, Shaw J: Global and societal implications of the diabetes epidemic. Nature 2001;414: 782-787.

23. Tuomilehto J: Strategies for primary prevention of non-insulin dependent diabetes mellitus. Adv Exp Med Biol 1988;246:403-411.

24. Buchanan TA, Xiang AH, Peters RK, Kjos SL, Marroquin A, Goico J, Ochoa C, Tan S, Berkowitz K, Hodis HN, Azen SP: Preservation of pancreatic beta-cell function and prevention of type 2 diabetes by pharmacological treatment of insulin resistance in highrisk Hispanic women. Diabetes 2002;51:2796-2803.

Address reprint requests to:
Ray C. Boston, Ph.D.
School of Veterinary Medicine
University of Pennsylvania
New Bolton Center
382 West Street Road
Kennett Square, PA 19348

E-mail: Boston@vet.upenn.edu 


\section{This article has been cited by:}

1. L.C. Marett, M.J. Auldist, P.J. Moate, W.J. Wales, K.L. Macmillan, F.R. Dunshea, B.J. Leury. 2015. Response of plasma glucose, insulin, and nonesterified fatty acids to intravenous glucose tolerance tests in dairy cows during a 670-day lactation. Journal of Dairy Science 98, 179-189. [CrossRef]

2. Lorraine E Levitt Katz, Kevin A Gralewski, Pamela Abrams, Preneet C Brar, Paul R Gallagher, Terri H Lipman, Lee J Brooks, Dorit Koren. 2014. Insulin-like growth factor-I and insulin-like growth factor binding protein-1 are related to cardiovascular disease biomarkers in obese adolescents. Pediatric Diabetes n/a-n/a. [CrossRef]

3. Jane F. Ferguson, Rhia Y. Shah, Rachana Shah, Nehal N. Mehta, Michael R. Rickels, Muredach P. Reilly. 2014. Activation of innate immunity modulates insulin sensitivity, glucose effectiveness and pancreatic $\beta$-cell function in both African ancestry and European ancestry healthy humans. Metabolism . [CrossRef]

4. Paul M. Coen, Charles J. Tanner, Nicole L. Helbling, Gabriel S. Dubis, Kazanna C. Hames, Hui Xie, George M. Eid, Maja Stefanovic-Racic, Frederico G.S. Toledo, John M. Jakicic, Joseph A. Houmard, Bret H. Goodpaster. 2014. Clinical trial demonstrates exercise following bariatric surgery improves insulin sensitivity. Journal of Clinical Investigation . [CrossRef]

5. M. Coradini, J.S. Rand, J.M. Morton, J.M. Rawlings. 2014. Metabolic determinants of body weight after cats were fed a low-carbohydrate high-protein diet or a high-carbohydrate low-protein diet ad libitum for 8 wk. Domestic Animal Endocrinology 49, 70-79. [CrossRef]

6. J.F. Ferguson, M.F. Ryan, E.R. Gibney, L. Brennan, H.M. Roche, M.P. Reilly. 2014. Dietary isoflavone intake is associated with evoked responses to inflammatory cardiometabolic stimuli and improved glucose homeostasis in healthy volunteers. Nutrition, Metabolism and Cardiovascular Diseases 24, 996-1003. [CrossRef]

7. Benjamin Leon, Bernard V. Miller, Gloria Zalos, Amber B. Courville, Anne E. Sumner, Tiffany M. Powell-Wiley, Mary F. Walter, Myron A. Waclawiw, Richard O. Cannon. 2014. Weight Loss Programs May Have Beneficial or Adverse Effects on Fat Mass and Insulin Sensitivity in Overweight and Obese Black Women. Journal of Racial and Ethnic Health Disparities 1, 140-147. [CrossRef]

8. Claudia M. Toledo-Corral, Tanya L. Alderete, Joyce Richey, Paola Sequeira, Michael I. Goran, Marc J. Weigensberg. 2014. Fasting, post-OGTT challenge, and nocturnal free fatty acids in prediabetic versus normal glucose tolerant overweight and obese Latino adolescents. Acta Diabetologica . [CrossRef]

9. O'Connor Michelle Y., Thoreson Caroline K., Ricks Madia, Courville Amber B., Thomas Francine, Yao Jianhua, Katzmarzyk Peter T., Sumner Anne E.. 2014. Worse Cardiometabolic Health in African Immigrant Men than African American Men: Reconsideration of the Healthy Immigrant Effect. Metabolic Syndrome and Related Disorders 12:6, 347-353. [Abstract] [Full Text HTML] [Full Text PDF] [Full Text PDF with Links]

10. M. May, J. Ahrens, J. Menne, H. Haller, J. Beige, S. Eckert, J. Jordan, S. Engeli. 2014. Limited Acute Influences of Electrical Baroreceptor Activation on Insulin Sensitivity and Glucose Delivery: A Randomized, Double-Blind, Crossover Clinical Study. Diabetes 63, 2833-2837. [CrossRef]

11. Jie Ren, Anny H. Xiang, Enrique Trigo, Miwa Takayanagi, Elizabeth Beale, Jean M. Lawrence, Jaana Hartiala, Joyce M. Richey, Hooman Allayee, Thomas A. Buchanan, Richard M. Watanabe. 2014. Genetic variation in MTNR1B is associated with gestational diabetes mellitus and contributes only to the absolute level of beta cell compensation in Mexican Americans. Diabetologia 57, 1391-1399. [CrossRef]

12. Federico Galvanin, Massimiliano Barolo, Sandro Macchietto, Fabrizio BezzoIdentification of Physiological Models of Type 1 Diabetes Mellitus by Model-Based Design of Experiments 545-581. [CrossRef]

13. M. Ader, D. Stefanovski, J. M. Richey, S. P. Kim, C. M. Kolka, V. Ionut, M. Kabir, R. N. Bergman. 2014. Failure of Homeostatic Model Assessment of Insulin Resistance to Detect Marked Diet-Induced Insulin Resistance in Dogs. Diabetes 63, 1914-1919. [CrossRef] 
14. R. Leproult, U. Holmback, E. Van Cauter. 2014. Circadian Misalignment Augments Markers of Insulin Resistance and Inflammation, Independently of Sleep Loss. Diabetes 63, 1860-1869. [CrossRef]

15. Marilyn Ader, Darko Stefanovski, Stella P. Kim, Joyce M. Richey, Viorica Ionut, Karyn J. Catalano, Katrin Hucking, Martin Ellmerer, Gregg Van Citters, Isabel R. Hsu, Jenny D. Chiu, Orison O. Woolcott, Lisa N. Harrison, Dan Zheng, Maya Lottati, Cathryn M. Kolka, Vahe Mooradian, Justin Dittmann, Sophia Yae, Huiwen Liu, Ana Valeria B. Castro, Morvarid Kabir, Richard N. Bergman. 2014. Hepatic insulin clearance is the primary determinant of insulin sensitivity in the normal dog. Obesity 22:10.1002/oby.v22.5, 1238-1245. [CrossRef]

16. N.J. Bamford, S.J. Potter, P.A. Harris, S.R. Bailey. 2014. Breed differences in insulin sensitivity and insulinemic responses to oral glucose in horses and ponies of moderate body condition score. Domestic Animal Endocrinology 47, 101-107. [CrossRef]

17. K H Lampinen, M Rönnback, P-H Groop, M G Nicholls, T G Yandle, R J Kaaja. 2014. Increased plasma norepinephrine levels in previously pre-eclamptic women. Journal of Human Hypertension 28, 269-273. [CrossRef]

18. P. C. Chandler-Laney, P. B. Higgins, W. Granger, J. Alvarez, K. Casazza, J. R. Fernandez, C. Dalla Man, C. Cobelli, B. A. Gower. 2014. Use of a simple liquid meal test to evaluate insulin sensitivity and betacell function in children. Pediatric Obesity 9:10.1111/ijpo.2014.9.issue-2, 102-110. [CrossRef]

19. Christian-Alexandre Castellano, Jean-Patrice Baillargeon, Mélanie Plourde, Sandie I. Briand, Paul Angers, Alain Giguère, J. Jacques Matte. 2014. Dietary conjugated $\alpha$-linolenic acid did not improve glucose tolerance in a neonatal pig model. European Journal of Nutrition 53, 761-768. [CrossRef]

20. Mudaliar Sunder, Henry Robert R., Boden Guenther, Smith Steven, Chalamandaris AlexandrosGeorgios, Duchesne Dominique, Iqbal Nayyar, List James. 2014. Changes in Insulin Sensitivity and Insulin Secretion with the Sodium Glucose Cotransporter 2 Inhibitor Dapagliflozin. Diabetes Technology \& Therapeutics 16:3, 137-144. [Abstract] [Full Text HTML] [Full Text PDF] [Full Text PDF with Links]

21. B Leon, S Jenkins, K Pepin, H Chaudhry, K Smith, G Zalos, B V Miller, K Y Chen, A T Remaley, M A Waclawiw, A E Sumner, R O Cannon. 2013. Insulin and extremity muscle mass in overweight and obese women. International Journal of Obesity 37, 1560-1564. [CrossRef]

22. M Westerståhl, P Hedvall Kallerman, E Hagman, A E Ek, S M Rössner, C Marcus. 2013. Nocturnal blood pressure non-dipping is prevalent in severely obese, prepubertal and early pubertal children. Acta Paediatrica n/a-n/a. [CrossRef]

23. Anny H. Xiang, Miwa Takayanagi, Mary Helen Black, Enrique Trigo, Jean M. Lawrence, Richard M. Watanabe, Thomas A. Buchanan. 2013. Longitudinal changes in insulin sensitivity and beta cell function between women with and without a history of gestational diabetes mellitus. Diabetologia 56, 2753-2760. [CrossRef]

24. S. Ahlin, K. Sjöholm, P. Jacobson, J.C. Andersson-Assarsson, A. Walley, J. Tordjman, C. Poitou, E. Prifti, P.-A. Jansson, J. Borén, L. Sjöström, P. Froguel, R.N. Bergman, L.M.S. Carlsson, B. Olsson, P.-A. Svensson. 2013. Macrophage Gene Expression in Adipose Tissue is Associated with Insulin Sensitivity and Serum Lipid Levels Independent of Obesity. Obesity 21:10.1002/oby.v21.12, E571-E576. [CrossRef]

25. R. Lundberg, G. J. Beilman, T. B. Dunn, T. L. Pruett, S. C. Chinnakotla, D. M. Radosevich, R. P. Robertson, P. Ptacek, A. N. Balamurugan, J. J. Wilhelm, B. J. Hering, D. E. R. Sutherland, A. Moran, M. D. Bellin. 2013. Metabolic Assessment Prior to Total Pancreatectomy and Islet Autotransplant: Utility, Limitations and Potential. American Journal of Transplantation 13:10.1111/ ajt.v13.10, 2664-2671. [CrossRef]

26. V. A. Lizunov, J.-P. Lee, M. C. Skarulis, J. Zimmerberg, S. W. Cushman, K. G. Stenkula. 2013. Impaired Tethering and Fusion of GLUT4 Vesicles in Insulin-Resistant Human Adipose Cells. Diabetes 62, 3114-3119. [CrossRef] 
27. Pablo Perez-Martinez, Antonio Garcia-Rios, Javier Delgado-Lista, Ingrid M.F. Gjelstad, James Gibney, Beata Kieć-Wilk, Antonio Camargo, Olfa Helal, Brita Karlström, Ellen E. Blaak, Wendy Hall, Ulf Risérus, Aldona Dembińska-Kieć, Catherine Defoort, Wim H.M. Saris, Julie A. Lovegrove, Christian A. Drevon, Helen M. Roche, Jose Lopez-Miranda. 2013. Gene-nutrient interactions on the phosphoenolpyruvate carboxykinase influence insulin sensitivity in metabolic syndrome subjects. Clinical Nutrition 32, 630-635. [CrossRef]

28. Elizabeth M. Tadros, Nicholas Frank, Fiamma Gomez De Witte, Raymond C. Boston. 2013. Effects of intravenous lipopolysaccharide infusion on glucose and insulin dynamics in horses with equine metabolic syndrome. American Journal of Veterinary Research 74, 1020-1029. [CrossRef]

29. Jenne D. De Koster, Geert Opsomer. 2013. Insulin Resistance in Dairy Cows. Veterinary Clinics of North America: Food Animal Practice 29, 299-322. [CrossRef]

30. Tanja M. Hess, Jill Rexford, Diana Karen Hansen, Nicolette Schauermann Ahrens, Mary Harris, Terry Engle, Trinette Ross, Kenneth G. Allen. 2013. Effects of $\Omega-3$ (n-3) Fatty Acid Supplementation on Insulin Sensitivity in Horses. Journal of Equine Veterinary Science 33, 446-453. [CrossRef]

31. Uta Schmengler, Julia Ungru, Ray Boston, Manfred Coenen, Ingrid Vervuert. 2013. Effects of 1-carnitine supplementation on body weight losses and metabolic profile in obese and insulin-resistant ponies during a 14-week body weight reduction programme. Livestock Science . [CrossRef]

32. Amanda Jiménez, Roser Casamitjana, Lílliam Flores, Salvadora Delgado, Antonio Lacy, Josep Vidal. 2013. GLP-1 and the Long-Term Outcome of Type 2 Diabetes Mellitus After Roux-en-Y Gastric Bypass Surgery in Morbidly Obese Subjects. Annals of Surgery 257, 894-899. [CrossRef]

33. M. Spencer, B. S. Finlin, R. Unal, B. Zhu, A. J. Morris, L. R. Shipp, J. Lee, R. G. Walton, A. Adu, R. Erfani, M. Campbell, R. E. McGehee, C. A. Peterson, P. A. Kern. 2013. Omega-3 Fatty Acids Reduce Adipose Tissue Macrophages in Human Subjects With Insulin Resistance. Diabetes 62, 1709-1717. [CrossRef]

34. Sophia S.K. Yu, Natalie L.M. Ramsey, Darleen C. Castillo, Madia Ricks, Anne E. Sumner. 2013. Triglyceride-Based Screening Tests Fail to Recognize Cardiometabolic Disease in African Immigrant and African-American Men. Metabolic Syndrome and Related Disorders 11:1, 15-20. [Abstract] [Full Text HTML] [Full Text PDF] [Full Text PDF with Links]

35. Anne E Sumner, Jeremy D Furtado, Amber B Courville, Madia Ricks, Novie Younger-Coleman, Marshall K Tulloch-Reid, Frank M Sacks. 2013. ApoC-III and visceral adipose tissue contribute to paradoxically normal triglyceride levels in insulin-resistant African-American women. Nutrition \& Metabolism 10, 73. [CrossRef]

36. Andréanne Trottier, Marie-Claude Battista, David H. Geller, Brigitte Moreau, André C. Carpentier, Judith Simoneau-Roy, Jean-Patrice Baillargeon. 2012. Adipose tissue insulin resistance in peripubertal girls with first-degree family history of polycystic ovary syndrome. Fertility and Sterility 98, 1627-1634. [CrossRef]

37. B. C. Bergman, L. Perreault, D. Hunerdosse, A. Kerege, M. Playdon, A. M. Samek, R. H. Eckel. 2012. Novel and Reversible Mechanisms of Smoking-Induced Insulin Resistance in Humans. Diabetes 61, 3156-3166. [CrossRef]

38. Anneke Jans, Anneke M.J. van Hees, Ingrid M.F. Gjelstad, Lauren M. Sparks, Audrey C. Tierney, Ulf Risérus, Christian A. Drevon, Patrick Schrauwen, Helen M. Roche, Ellen E. Blaak. 2012. Impact of dietary fat quantity and quality on skeletal muscle fatty acid metabolism in subjects with the metabolic syndrome. Metabolism 61, 1554-1565. [CrossRef]

39. M. Henderson, J.P. Baillargeon, R. Rabasa-Lhoret, J.L. Chiasson, J. Hanley, M. Lambert. 2012. Estimating insulin secretion in youth using simple indices derived from the oral glucose tolerance test. Diabetes \& Metabolism 38, 309-315. [CrossRef]

40. J. Scott Gabrielsen, Yan Gao, Judith A. Simcox, Jingyu Huang, David Thorup, Deborah Jones, Robert C. Cooksey, David Gabrielsen, Ted D. Adams, Steven C. Hunt, Paul N. Hopkins, William T. Cefalu, 
Donald A. McClain. 2012. Adipocyte iron regulates adiponectin and insulin sensitivity. Journal of Clinical Investigation 122, 3529-3540. [CrossRef]

41. Claudia O. Zein, Rocio Lopez, Xiaoming Fu, John P. Kirwan, Lisa M. Yerian, Arthur J. McCullough, Stanley L. Hazen, Ariel E. Feldstein. 2012. Pentoxifylline decreases oxidized lipid products in nonalcoholic steatohepatitis: New evidence on the potential therapeutic mechanism. Hepatology 56:10.1002/hep.v56.4, 1291-1299. [CrossRef]

42. F. Andreelli. 2012. Métabolisme des glucides et méthodes d'exploration chez l'homme. EMC Endocrinologie - Nutrition 9, 1-13. [CrossRef]

43. David Bradley, Faidon Magkos, Samuel Klein. 2012. Effects of Bariatric Surgery on Glucose Homeostasis and Type 2 Diabetes. Gastroenterology 143, 897-912. [CrossRef]

44. Caroline Messer, Raymond Boston, Derek Leroith, Eliza Geer, Joshua D. Miller, Marcelo Messer, Walter Futterweit. 2012. Pancreatic $\beta$-Cell Dysfunction in Polycystic Ovary Syndrome: The Role of Metformin. Endocrine Practice 18, 685-693. [CrossRef]

45. Daniel J. Lesser, Rajeev Bhatia, Winston H. Tran, Flavia Oliveira, Ricardo Ortega, Thomas G. Keens, Steven D. Mittelman, Michael C.K. Khoo, Sally L. Davidson Ward. 2012. Sleep fragmentation and intermittent hypoxemia are associated with decreased insulin sensitivity in obese adolescent Latino males. Pediatric Research 72, 293-298. [CrossRef]

46. S. Salin, J. Taponen, K. Elo, I. Simpura, A. Vanhatalo, R. Boston, T. Kokkonen. 2012. Effects of abomasal infusion of tallow or camelina oil on responses to glucose and insulin in dairy cows during late pregnancy. Journal of Dairy Science 95, 3812-3825. [CrossRef]

47. Kevin MakiMeasurement Techniques for Insulin Sensitivity 57-70. [CrossRef]

48. B. A. Wicklow, K. D. M. Wittmeier, A. C. MacIntosh, E. A. C. Sellers, L. Ryner, H. Serrai, H. J. Dean, J. M. McGavock. 2012. Metabolic Consequences of Hepatic Steatosis in Overweight and Obese Adolescents. Diabetes Care 35, 905-910. [CrossRef]

49. B. C. Bergman, D. M. Hunerdosse, A. Kerege, M. C. Playdon, L. Perreault. 2012. Localisation and composition of skeletal muscle diacylglycerol predicts insulin resistance in humans. Diabetologia . [CrossRef]

50. Kristy D.M. Wittmeier, Brandy A. Wicklow, Andrea C. MacIntosh, Elizabeth A.C. Sellers, Lawrence N. Ryner, Hacene Serrai, Philip F. Gardiner, Heather J. Dean, Jonathan M. McGavock. 2012. Hepatic Steatosis and Low Cardiorespiratory Fitness in Youth With Type 2 Diabetes. Obesity . [CrossRef]

51. Nehal N Mehta, Sean P Heffron, Parth N Patel, Jane Ferguson, Rachana D Shah, Christine C Hinkle, Parasuram Krishnamoorthy, Rhia Shah, Jennifer Tabita-Martinez, Karen Terembula, Stephen R Master, Michael R Rickels, Muredach P Reilly. 2012. A human model of inflammatory cardio-metabolic dysfunction; a double blind placebo-controlled crossover trial. Journal of Translational Medicine 10, 124. [CrossRef]

52. Matthias Chung, Eldad Haber. 2012. Experimental Design for Biological Systems. SIAM Journal on Control and Optimization 50, 471-489. [CrossRef]

53. N.R. Liburt, M.N. Fugaro, K. Malinowski, E.K. Wunderlich, J.L. Zambito, D.W. Horohov, A. Betancourt, R.C. Boston, R.J. Geor, J. Onishi, K.H. McKeever. 2012. The effect of age and exercise training on insulin sensitivity, fat and muscle tissue cytokine profiles and body composition of old and young Standardbred mares. Comparative Exercise Physiology 8, 173-187. [CrossRef]

54. Eric J. Chow, Catherine Pihoker, Debra L. Friedman, Stephanie J. Lee, Jeannine S. McCune, Claire Wharton, Christian L. Roth, K. Scott Baker. 2012. Glucocorticoids and insulin resistance in children with acute lymphoblastic leukemia. Pediatric Blood \& Cancer n/a-n/a. [CrossRef]

55. Pablo Perez-Martinez, Javier Delgado-Lista, Antonio Garcia-Rios, Audrey C. Tierney, Hanne L. Gulseth, Christine M. Williams, Brita Karlström, Beata Kieć-Wilk, Ellen E. Blaak, Olfa Helal, Wim H. M. Saris, Catherine Defoort, Christian A. Drevon, Julie A. Lovegrove, Aldona Dembinska-Kieć, Ulf Riserus, Helen M. Roche, Jose Lopez-Miranda. 2011. Insulin receptor substrate-2 gene variants in 
subjects with metabolic syndrome: Association with plasma monounsaturated and $n-3$ polyunsaturated fatty acid levels and insulin resistance. Molecular Nutrition \& Food Research n/a-n/a. [CrossRef]

56. Nishanth E. Sunny, Elizabeth J. Parks, Jeffrey D. Browning, Shawn C. Burgess. 2011. Excessive Hepatic Mitochondrial TCA Cycle and Gluconeogenesis in Humans with Nonalcoholic Fatty Liver Disease. Cell Metabolism 14, 804-810. [CrossRef]

57. W. K. McGee, C. V. Bishop, A. Bahar, C. R. Pohl, R. J. Chang, J. C. Marshall, F. K. Pau, R. L. Stouffer, J. L. Cameron. 2011. Elevated androgens during puberty in female rhesus monkeys lead to increased neuronal drive to the reproductive axis: a possible component of polycystic ovary syndrome. Human Reproduction . [CrossRef]

58. D. Koren, L. E. Levitt Katz, P. C. Brar, P. R. Gallagher, R. I. Berkowitz, L. J. Brooks. 2011. Sleep Architecture and Glucose and Insulin Homeostasis in Obese Adolescents. Diabetes Care 34, 2442-2447. [CrossRef]

59. M. Coradini, J. S. Rand, J. M. Morton, J. M. Rawlings. 2011. Effects of two commercially available feline diets on glucose and insulin concentrations, insulin sensitivity and energetic efficiency of weight gain. British Journal of Nutrition 106, S64-S77. [CrossRef]

60. Naviyn Prabhu Balakrishnan, Gade Pandu Rangaiah, Lakshminarayanan Samavedham. 2011. Review and Analysis of Blood Glucose (BG) Models for Type 1 Diabetic Patients. Industrial \& Engineering Chemistry Research 110929081457002. [CrossRef]

61. Brian Bennett, D. Enette Larson-Meyer, Eric Ravussin, Julia Volaufova, Arlette Soros, William T. Cefalu, Stuart Chalew, Stewart Gordon, Steven R. Smith, Bradley R. Newcomer, Michael Goran, Melinda Sothern. 2011. Impaired Insulin Sensitivity and Elevated Ectopic Fat in Healthy Obese vs. Nonobese Prepubertal Children. Obesity . [CrossRef]

62. M Vaittinen, M Kolehmainen, U Schwab, M Uusitupa, L Pulkkinen. 2011. Microfibrillar-associated protein 5 is linked with markers of obesity-related extracellular matrix remodeling and inflammation. Nutrition and Diabetes 1, e15. [CrossRef]

63. Maria A. Ramos-Roman, Lawrence Sweetman, Maressa J. Valdez, Elizabeth J. Parks. 2011. Postprandial changes in plasma acylcarnitine concentrations as markers of fatty acid flux in overweight and obesity. Metabolism . [CrossRef]

64. K. A. CHAMEROY, N. FRANK, S. B. ELLIOTT, R. C. BOSTON. 2011. Effects of a supplement containing chromium and magnesium on morphometric measurements, resting glucose, insulin concentrations and insulin sensitivity in laminitic obese horses. Equine Veterinary Journal 43, 494-499. [CrossRef]

65. Anneke M.J. van Hees, Anneke Jans, Gabby B. Hul, Helen M. Roche, Wim H.M. Saris, Ellen E. Blaak. 2011. Skeletal Muscle Fatty Acid Handling in Insulin Resistant Men. Obesity 19, 1350-1359. [CrossRef]

66. Aiwei Yao-Borengasser, Vijayalakshmi Varma, Robert H. Coker, Gouri Ranganathan, Bounleut Phanavanh, Neda Rasouli, Philip A. Kern. 2011. Adipose triglyceride lipase expression in human adipose tissue and muscle. Role in insulin resistance and response to training and pioglitazone. Metabolism 60, 1012-1020. [CrossRef]

67. Federico Galvanin, Massimiliano Barolo, Sandro Macchietto, Fabrizio BezzoIdentification of Physiological Models of Type 1 Diabetes Mellitus by Model-Based Design of Experiments 545-581. [CrossRef]

68. Anneke Jans, Lauren M. Sparks, Anneke M.J. van Hees, Ingrid M.F. Gjelstad, Audrey C. Tierney, Ulf Risérus, Christian A. Drevon, Helen M. Roche, Patrick Schrauwen, Ellen E. Blaak. 2011. Transcriptional Metabolic Inflexibility in Skeletal Muscle Among Individuals With Increasing Insulin Resistance. Obesity . [CrossRef]

69. Shaban Nazarian, John V. St. Peter, Raymond C. Boston, Sidney A. Jones, Cary N. Mariash. 2011. Vitamin D3 supplementation improves insulin sensitivity in subjects with impaired fasting glucose. Translational Research . [CrossRef] 
70. Leona Plum, Leaque Ahmed, Gerardo Febres, Marc Bessler, William Inabnet, Elizabeth Kunreuther, Donald J. McMahon, Judith Korner. 2011. Comparison of Glucostatic Parameters After Hypocaloric Diet or Bariatric Surgery and Equivalent Weight Loss. Obesity . [CrossRef]

71. Anwar Borai, Callum Livingstone, Fatima Abdelaal, Ali Bawazeer, Vuyolethu Keti, Gordon Ferns. 2011. The relationship between glycosylated haemoglobin (HbA1c) and measures of insulin resistance across a range of glucose tolerance. Scandinavian Journal of Clinical \& Laboratory Investigation 1-5. [CrossRef]

72. M. Henderson, R. Rabasa-Lhoret, J.-P. Bastard, J.-L. Chiasson, J.-P. Baillargeon, J.A. Hanley, M. Lambert. 2011. Measuring insulin sensitivity in youth: How do the different indices compare with the gold-standard method?. Diabetes \& Metabolism 37, 72-78. [CrossRef]

73. Susanne B. Votruba, Michael D. Jensen. 2011. Insulin Sensitivity and Regional Fat Gain in Response to Overfeeding. Obesity 19, 269-275. [CrossRef]

74. Kellie D. Tinworth, Ray C. Boston, Patricia A. Harris, Martin N. Sillence, Sharanne L. Raidal, Glenys K. Noble. 2011. The effect of oral metformin on insulin sensitivity in insulin-resistant ponies. The Veterinary Journal . [CrossRef]

75. K.-A. Le, E. E. Ventura, J. Q. Fisher, J. N. Davis, M. J. Weigensberg, M. Punyanitya, H. H. Hu, K. S. Nayak, M. I. Goran. 2011. Ethnic Differences in Pancreatic Fat Accumulation and Its Relationship With Other Fat Depots and Inflammatory Markers. Diabetes Care 34, 485-490. [CrossRef]

76. Claudia O. Zein, Lisa M. Yerian, Prema Gogate, Rocio Lopez, John P. Kirwan, Ariel E. Feldstein, Arthur J. McCullough. 2011. Pentoxifylline improves nonalcoholic steatohepatitis: A randomized placebocontrolled trial. Hepatology n/a-n/a. [CrossRef]

77. P Frisk, S M Rössner, S Norgren, J Arvidson, J Gustafsson. 2010. Glucose metabolism and body composition in young adults treated with TBI during childhood. Bone Marrow Transplantation. [CrossRef]

78. Anne E. Sumner, Jie Zhou, Ayo Doumatey, Omoye E. Imoisili, Albert Amoah, Joseph Acheampong, Johnnie Oli, Thomas Johnson, Clement Adebamowo, Charles N. Rotimi. 2010. Low HDL-cholesterol with normal triglyceride levels is the most common lipid pattern in West Africans and African Americans with Metabolic Syndrome: Implications for cardiovascular disease prevention. CVD Prevention and Control 5, 75-80. [CrossRef]

79. Elisa Fabbrini, Robyn A. Tamboli, Faidon Magkos, Pamela A. Marks-Shulman, Aaron W. Eckhauser, William O. Richards, Samuel Klein, Naji N. Abumrad. 2010. Surgical Removal of Omental Fat Does Not Improve Insulin Sensitivity and Cardiovascular Risk Factors in Obese Adults. Gastroenterology 139, 448-455. [CrossRef]

80. R. W. J. Leunissen, Y. Gao, K. Cianflone, T. Stijnen, A. C. S. Hokken-Koelega. 2010. Growth patterns during childhood and the relationship with acylation-stimulating protein. Clinical Endocrinology 72, 775-780. [CrossRef]

81. A M J van Hees, W H M Saris, G B Hul, N C Schaper, B E Timmerman, J A Lovegrove, H M Roche, E E Blaak. 2010. Effects of dietary fat modification on skeletal muscle fatty acid handling in the metabolic syndrome. International Journal of Obesity 34, 859-870. [CrossRef]

82. D. van der Kaay, B. Bakker, F. van der Hulst, D. Mul, J. Mulder, E. Schroor, D. van Elswijk, I. Rowaan, M. Willeboer, M. de Ridder, A. Hokken-Koelega. 2010. Randomized GH trial with two different dosages in combination with a GnRH analogue in short small for gestational age children: effects on metabolic profile and serum GH, IGF1, and IGFBP3 levels. European Journal of Endocrinology 162, 887-895. [CrossRef]

83. Anwar Borai, Callum Livingstone, Shahida Shafi, Hawzen Zarif, Gordon Ferns. 2010. Insulin sensitivity (Si) assessment in lean and overweight subjects using two different protocols and updated software. Scandinavian Journal of Clinical \& Laboratory Investigation 70, 98-103. [CrossRef]

84. S.-M. Ruchat, T. Rankinen, S. J. Weisnagel, T. Rice, D. C. Rao, R. N. Bergman, C. Bouchard, L. Pérusse. 2010. Improvements in glucose homeostasis in response to regular exercise are influenced by 
the PPARG Pro12Ala variant: results from the HERITAGE Family Study. Diabetologia 53, 679-689. [CrossRef]

85. H. L. Gulseth, I. M. F. Gjelstad, A. C. Tierney, J. A. Lovegrove, C. Defoort, E. E. Blaak, J. LopezMiranda, B. Kiec-Wilk, U. Ris, H. M. Roche, C. A. Drevon, K. I. Birkeland. 2010. Serum Vitamin D Concentration Does Not Predict Insulin Action or Secretion in European Subjects With the Metabolic Syndrome. Diabetes Care 33, 923-925. [CrossRef]

86. Sandra W. K. De Kort, Dennis O. Mook-Kanamori, Vincent W. V. Jaddoe, Anita C. S. Hokken-Koelega. 2010. Interactions between TCF7L2 genotype and growth hormone-induced changes in glucose homeostasis in small for gestational age children. Clinical Endocrinology 72:10.1111/cen.2009.72.issue-1, 47-52. [CrossRef]

87. N. N. Mehta, F. C. McGillicuddy, P. D. Anderson, C. C. Hinkle, R. Shah, L. Pruscino, J. TabitaMartinez, K. F. Sellers, M. R. Rickels, M. P. Reilly. 2010. Experimental Endotoxemia Induces Adipose Inflammation and Insulin Resistance in Humans. Diabetes 59, 172-181. [CrossRef]

88. Anwar Borai, Callum Livingstone, Hawazen Zarif, Shweta Mehta, Mona Kholeif, Mohammed Abdelaal, Hanin Al-Ghamdi, Gordon Ferns. 2009. A comparative study of insulin resistance for Saudi and Caucasian subjects across a range of glycaemic categories. Diabetes \& Metabolic Syndrome: Clinical Research \& Reviews 3, 204-210. [CrossRef]

89. F. TÓTH, N. FRANK, K. A. CHAMEROY, R. C. BOSTON. 2009. Effects of endotoxaemia and carbohydrate overload on glucose and insulin dynamics and the development of laminitis in horses. Equine Veterinary Journal 41, 852-858. [CrossRef]

90. A. E. DURHAM, K. J. HUGHES, H. J. COTTLE, D. I. RENDLE, R. C. BOSTON. 2009. Type 2 diabetes mellitus with pancreatic $\beta$ cell dysfunction in 3 horses confirmed with minimal model analysis. Equine Veterinary Journal 41, 924-929. [CrossRef]

91. X. Li, Y.-H. Shu, A. H. Xiang, E. Trigo, J. Kuusisto, J. Hartiala, A. J. Swift, M. Kawakubo, H. M. Stringham, L. L. Bonnycastle, J. M. Lawrence, M. Laakso, H. Allayee, T. A. Buchanan, R. M. Watanabe. 2009. Additive Effects of Genetic Variation in GCK and G6PC2 on Insulin Secretion and Fasting Glucose. Diabetes 58, 2946-2953. [CrossRef]

92. B. C. Bergman, L. Perreault, D. M. Hunerdosse, M. C. Koehler, A. M. Samek, R. H. Eckel. 2009. Intramuscular Lipid Metabolism in the Insulin Resistance of Smoking. Diabetes 58, 2220-2227. [CrossRef]

93. Matthew E. Talbert, Carl D. Langefeld, Julie T. Ziegler, Steven M. Haffner, Jill M. Norris, Donald W. Bowden. 2009. INSIG2 SNPs Associated With Obesity and Glucose Homeostasis Traits in Hispanics: The IRAS Family Study. Obesity 17, 1554-1562. [CrossRef]

94. Sandra W. K. de Kort, Ruben H. Willemsen, Danielle C. M. van der Kaay, Anita C. S. HokkenKoelega. 2009. The effect of growth hormone treatment on metabolic and cardiovascular risk factors is similar in preterm and term short, small for gestational age children. Clinical Endocrinology 71:10.1111/ cen.2009.71.issue-1, 65-73. [CrossRef]

95. Richard S. Surwit, James D. Lane, David S. Millington, Haoyue Zhang, Mark N. Feinglos, Sharon Minda, Rhonda Merwin, Cynthia M. Kuhn, Raymond C. Boston, Anastasia Georgiades. 2009. Hostility and Minimal Model of Glucose Kinetics in African American Women. Psychosomatic Medicine 71, 646-651. [CrossRef]

96. Donna Spruijt-Metz, Britni Belcher, David Anderson, Christianne Joy Lane, Chih-Ping Chou, Dawna Salter-Venzon, Jaimie N. Davis, Ya-Wen Janice Hsu, Marian L. Neuhouser, Joyce M. Richey. 2009. A High-Sugar/Low-Fiber Meal Compared with a Low-Sugar/High-Fiber Meal Leads to Higher Leptin and Physical Activity Levels in Overweight Latina Females. Journal of the American Dietetic Association 109, 1058-1063. [CrossRef]

97. Karen A. Kalck, Nicholas Frank, Sarah B. Elliott, Raymond C. Boston. 2009. Effects of low-dose oligofructose treatment administered via nasogastric intubation on induction of laminitis and associated 
alterations in glucose and insulin dynamics in horses. American Journal of Veterinary Research 70, 624-632. [CrossRef]

98. Nayyar Iqbal, Serena Cardillo, Sheri Volger, LeAnne T. Bloedon, Richard A. Anderson, Raymond Boston, Philippe O. Szapary. 2009. Chromium Picolinate Does Not Improve Key Features of Metabolic Syndrome in Obese Nondiabetic Adults. Metabolic Syndrome and Related Disorders 7:2, 143-150. [Abstract] [Full Text HTML] [Full Text PDF] [Full Text PDF with Links]

99. Lanyi Xie, R. P. Hoffman, Peter Veng-Pedersen. 2009. Noncompartmental pharmacokinetics analysis of glucose-stimulated insulin response in African-American and Caucasian youths. Biopharmaceutics \& Drug Disposition 30:10.1002/bdd.v30:3, 117-125. [CrossRef]

100. Xia Li, Hooman Allayee, Anny H. Xiang, Enrique Trigo, Jaana Hartiala, Jean M. Lawrence, Thomas A. Buchanan, Richard M. Watanabe. 2009. Variation in IGF2BP2 Interacts With Adiposity to Alter Insulin Sensitivity in Mexican Americans. Obesity 17, 729-736. [CrossRef]

101. Anne E. Sumner, Marcella F. Luercio, Barbara A. Frempong, Madia Ricks, Sabyasachi Sen, Harvey Kushner, Marshall K. Tulloch-Reid. 2009. Validity of the reduced-sample insulin modified frequentlysampled intravenous glucose tolerance test using the nonlinear regression approach. Metabolism 58, 220-225. [CrossRef]

102. Judith L. Gooley, Jacqueline M. Walters, Glenn M. Ward. 2009. The Minimal Model of Glucose Disposal in the Analysis of Glucose Effectiveness: Importance of Early Insulin Data. Diabetes Technology \& Therapeutics 11:1, 25-30. [Abstract] [Full Text PDF] [Full Text PDF with Links]

103. S. R. Vethakkan, J. M. Walters, J. L. Gooley, R. C. Boston, G. M. Ward. 2009. Application of the intravenous glucose tolerance test and the minimal model to patients with insulinoma: insulin sensitivity (Si) and glucose effectiveness (Sg) before and after surgical excision. Clinical Endocrinology 70:10.1111/ cen.2009.70.issue-1, 47-52. [CrossRef]

104. R. LOOMBA, G. LUTCHMAN, D. E. KLEINER, M. RICKS, J. J. FELD, B. B. BORG, A. MODI, P. NAGABHYRU, A. E. SUMNER, T. J. LIANG, J. H. HOOFNAGLE. 2009. Clinical trial: pilot study of metformin for the treatment of non-alcoholic steatohepatitis. Alimentary Pharmacology \& Therapeutics 29:10.1111/apt.2008.29.issue-2, 172-182. [CrossRef]

105. V. D. F. Mello, M. Kolehmainen, L. Pulkkinen, U. Schwab, U. Mager, D. E. Laaksonen, L. Niskanen, H. Gylling, M. Atalay, R. Rauramaa, M. Uusitupa. 2008. Downregulation of genes involved in NF $\varkappa B$ activation in peripheral blood mononuclear cells after weight loss is associated with the improvement of insulin sensitivity in individuals with the metabolic syndrome: the GENOBIN study. Diabetologia 51, 2060-2067. [CrossRef]

106. April J. Stull, John P. Thyfault, Mark D. Haub, Richard E. Ostlund, Wayne W. Campbell. 2008. Relationships between urinary inositol excretions and whole-body glucose tolerance and skeletal muscle insulin receptor phosphorylation. Metabolism 57, 1545-1551. [CrossRef]

107. Marilyn Ader, W. Timothy Garvey, Lawrence S. Phillips, Charles B. Nemeroff, Georges Gharabawi, Ramy Mahmoud, Andrew Greenspan, Sally A. Berry, Dominique L. Musselman, Jacqueline Morein, Young Zhu, Lian Mao, Richard N. Bergman. 2008. Ethnic heterogeneity in glucoregulatory function during treatment with atypical antipsychotics in patients with schizophrenia. Journal of Psychiatric Research 42, 1076-1085. [CrossRef]

108. C. Koebnick, L. A. Kelly, C. J. Lane, C. K. Roberts, G. Q. Shaibi, C. M. Toledo-Corral, J. N. Davis, M. J. Weigensberg, M. I. Goran. 2008. Combined association of maternal and paternal family history of diabetes with plasma leptin and adiponectin in overweight Hispanic children. Diabetic Medicine 25:10.1111/dme.2008.25.issue-9, 1043-1048. [CrossRef]

109. Anne E. Sumner, Sabyasachi Sen, Madia Ricks, Barbara A. Frempong, Nancy G. Sebring, Harvey Kushner. 2008. Determining the Waist Circumference in African Americans Which Best Predicts Insulin Resistance. Obesity 16, 841-846. [CrossRef]

110. U. Mager, M. Kolehmainen, V. D F de Mello, U. Schwab, D. E Laaksonen, R. Rauramaa, H. Gylling, M. Atalay, L. Pulkkinen, M. Uusitupa. 2008. Expression of ghrelin gene in peripheral blood mononuclear 
cells and plasma ghrelin concentrations in patients with metabolic syndrome. European Journal of Endocrinology 158, 499-510. [CrossRef]

111. M Kolehmainen, T Salopuro, U S Schwab, J Kekäläinen, P Kallio, D E Laaksonen, L Pulkkinen, V I Lindi, K Sivenius, U Mager, N Siitonen, L Niskanen, H Gylling, R Rauramaa, M Uusitupa. 2008. Weight reduction modulates expression of genes involved in extracellular matrix and cell death: the GENOBIN study. International Journal of Obesity 32, 292-303. [CrossRef]

112. Vanessa D.F. de Mello, Marjukka Kolehmainen, Ursula Schwab, Ursula Mager, David E. Laaksonen, Leena Pulkkinen, Leo Niskanen, Helena Gylling, Mustafa Atalay, Rainer Rauramaa, Matti Uusitupa. 2008. Effect of weight loss on cytokine messenger RNA expression in peripheral blood mononuclear cells of obese subjects with the metabolic syndrome. Metabolism 57, 192-199. [CrossRef]

113. V. Varma, A. Yao-Borengasser, A. M. Bodles, N. Rasouli, B. Phanavanh, G. T. Nolen, E. M. Kern, R. Nagarajan, H. J. Spencer, M.-J. Lee, S. K. Fried, R. E. McGehee, C. A. Peterson, P. A. Kern. 2008. Thrombospondin-1 Is an Adipokine Associated With Obesity, Adipose Inflammation, and Insulin Resistance. Diabetes 57, 432-439. [CrossRef]

114. Ferenc Tóth, Nicholas Frank, Sarah B. Elliott, Raymond J. Geor, Raymond C. Boston. 2008. Effects of an intravenous endotoxin challenge on glucose and insulin dynamics in horses. American Journal of Veterinary Research 69, 82-88. [CrossRef]

115. Nicholas Frank, Sarah B. Elliott, Raymond C. Boston. 2008. Effects of long-term oral administration of levothyroxine sodium on glucose dynamics in healthy adult horses. American Journal of Veterinary Research 69, 76-81. [CrossRef]

116. Sophie E. Yeo, Robert H. Coker. 2008. Aerobic exercise training versus the aetiology of insulin resistance. European Journal of Sport Science 8, 3-14. [CrossRef]

117. Simon R. Bailey, Nicola J. Menzies-Gow, Patricia A. Harris, Jocelyn L. Habershon-Butcher, Carol Crawford, Yoel Berhane, Raymond C. Boston, Jonathan Elliott. 2007. Effect of dietary fructans and dexamethasone administration on the insulin response of ponies predisposed to laminitis. Journal of the American Veterinary Medical Association 231, 1365-1373. [CrossRef]

118. Peter J Moate, John R Roche, Lucia M Chagas, Raymond C Boston. 2007. Evaluation of a compartmental model to describe non-esterified fatty acid kinetics in Holstein dairy cows. Journal of Dairy Research 74. . [CrossRef]

119. Colleen Hadigan, James Liebau, Rebecca Andersen, Nagaraj-Setty Holalkere, Dushyant V Sahani. 2007. Magnetic Resonance Spectroscopy of Hepatic Lipid Content and Associated Risk Factors in HIV Infection. JAIDS Journal of Acquired Immune Deficiency Syndromes 46, 312-317. [CrossRef]

120. Audrey C. Tierney, Helen M. Roche. 2007. The potential role of olive oil-derived MUFA in insulin sensitivity. Molecular Nutrition \& Food Research 51:10.1002/mnfr.v51:10, 1235-1248. [CrossRef]

121. M. Teran-Garcia, T. Rankinen, T. Rice, A. S. Leon, D. C. Rao, J. S. Skinner, C. Bouchard. 2007. Variations in the four and a half LIM domains 1 gene (FHL1) are associated with fasting insulin and insulin sensitivity responses to regular exercise. Diabetologia 50, 1858-1866. [CrossRef]

122. M HALLIKAINEN, M KOLEHMAINEN, U SCHWAB, D LAAKSONEN, L NISKANEN, R RAURAMAA, J PIHLAJAMAKI, M UUSITUPA, T MIETTINEN, H GYLLING. 2007. Serum adipokines are associated with cholesterol metabolism in the metabolic syndrome. Clinica Chimica Acta 383, 126-132. [CrossRef]

123. S. C. Elbein, W. S. Chu, S. K. Das, A. Yao-Borengasser, S. J. Hasstedt, H. Wang, N. Rasouli, P. A. Kern. 2007. Transcription factor 7-like 2 polymorphisms and type 2 diabetes, glucose homeostasis traits and gene expression in US participants of European and African descent. Diabetologia 50, 1621-1630. [CrossRef]

124. R. N. Bergman. 2007. Orchestration of Glucose Homeostasis: From a Small Acorn to the California Oak. Diabetes 56, 1489-1501. [CrossRef] 
125. Rebekah L. Craig, Winston S. Chu, Steven C. Elbein. 2007. Retinol binding protein 4 as a candidate gene for type 2 diabetes and prediabetic intermediate traits. Molecular Genetics and Metabolism 90, 338-344. [CrossRef]

126. W. S. Chu, S. K. Das, H. Wang, J. C. Chan, P. Deloukas, P. Froguel, L. J. Baier, W. Jia, M. I. McCarthy, M. C.Y. Ng, C. Damcott, A. R. Shuldiner, E. Zeggini, S. C. Elbein. 2007. Activating Transcription Factor 6 (ATF6) Sequence Polymorphisms in Type 2 Diabetes and Pre-Diabetic Traits. Diabetes 56, 856-862. [CrossRef]

127. Raymond C. Boston, Darko Stefanovski, Jan E. Henriksen, Glen M. Ward, Peter J. Moate. 2007. AKATPG: A Program for Kinetic and Epidemiological Analysis of Data from Labeled Glucose Investigations Using the Two-Pool Model and Database Technology. Diabetes Technology \& Therapeutics 9:1, 99-108. [Abstract] [Full Text PDF] [Full Text PDF with Links]

128. N. E. Wolins, B. K. Quaynor, J. R. Skinner, A. Tzekov, M. A. Croce, M. C. Gropler, V. Varma, A. YaoBorengasser, N. Rasouli, P. A. Kern, B. N. Finck, P. E. Bickel. 2006. OXPAT/PAT-1 Is a PPAR-Induced Lipid Droplet Protein That Promotes Fatty Acid Utilization. Diabetes 55, 3418-3428. [CrossRef]

129. D. Abraham, J. Rogers, P. Gault, J. P. Kushner, D. A. McClain. 2006. Increased insulin secretory capacity but decreased insulin sensitivity after correction of iron overload by phlebotomy in hereditary haemochromatosis. Diabetologia 49, 2546-2551. [CrossRef]

130. S. C. Elbein, X. Wang, M. A. Karim, B. I. Freedman, D. W. Bowden, A. R. Shuldiner, F. L. Brancati, W. H. L. Kao. 2006. Role of a Proline Insertion in the Insulin Promoter Factor 1 (IPF1) Gene in African Americans With Type 2 Diabetes. Diabetes 55, 2909-2914. [CrossRef]

131. E. Zeggini, C. M. Damcott, R. L. Hanson, M. A. Karim, N. W. Rayner, C. J. Groves, L. J. Baier, T. C. Hale, A. T. Hattersley, G. A. Hitman, S. E. Hunt, W. C. Knowler, B. D. Mitchell, M. C.Y. Ng, J. R. O'Connell, T. I. Pollin, M. Vaxillaire, M. Walker, X. Wang, P. Whittaker, K. Xiang, W. Jia, J. C. N. Chan, P. Froguel, P. Deloukas, A. R. Shuldiner, S. C. Elbein, M. I. McCarthy. 2006. Variation Within the Gene Encoding the Upstream Stimulatory Factor 1 Does Not Influence Susceptibility to Type 2 Diabetes in Samples From Populations With Replicated Evidence of Linkage to Chromosome 1q. Diabetes 55, 2541-2548. [CrossRef]

132. K. H. TREIBER, T. M. HESS, D. S. KRONFELD, R. C. BOSTON, R. J. GEOR, M. FRIERE, A. M. G. B. SILVA, P. A. HARRIS. 2006. Glucose dynamics during exercise: dietary energy sources affect minimal model parameters in trained Arabian geldings during endurance exercise. Equine Veterinary Journal 38, 631-636. [CrossRef]

133. D. A. McClain, D. Abraham, J. Rogers, R. Brady, P. Gault, R. Ajioka, J. P. Kushner. 2006. High prevalence of abnormal glucose homeostasis secondary to decreased insulin secretion in individuals with hereditary haemochromatosis. Diabetologia 49, 1661-1669. [CrossRef]

134. D. E. Larson-Meyer, L. K. Heilbronn, L. M. Redman, B. R. Newcomer, M. I. Frisard, S. Anton, S. R. Smith, A. Alfonso, E. Ravussin. 2006. Effect of Calorie Restriction With or Without Exercise on Insulin Sensitivity, -Cell Function, Fat Cell Size, and Ectopic Lipid in Overweight Subjects. Diabetes Care 29, 1337-1344. [CrossRef]

135. J HELGE, K OVERGAARD, R DAMSGAARD, K SORENSEN, J ANDERSEN, S DYRSKOG, K HERMANSEN, B SALTIN, J WOJTASZEWSKI. 2006. Repeated prolonged whole-body lowintensity exercise: effects on insulin sensitivity and limb muscle adaptations. Metabolism 55, 217-223. [CrossRef]

136. A SUMNER, G VEGA, D GENOVESE, K FINLEY, R BERGMAN, R BOSTON. 2005. Normal triglyceride levels despite insulin resistance in African Americans: role of lipoprotein lipase. Metabolism 54, 902-909. [CrossRef]

137. K. A. McLachlan, R. Boston, F. P. Alford. 2005. Impaired non-esterified fatty acid suppression to intravenous glucose during late pregnancy persists postpartum in gestational diabetes: a dominant role for decreased insulin secretion rather than insulin resistance. Diabetologia 48, 1373-1379. [CrossRef] 
138. M. Teran-Garcia, N. Santoro, T. Rankinen, J. Bergeron, T. Rice, A. S. Leon, D.C. Rao, J. S. Skinner, R. N. Bergman, J.-P. Despres, C. Bouchard. 2005. Hepatic Lipase Gene Variant -514C >T Is Associated With Lipoprotein and Insulin Sensitivity Response to Regular Exercise: The HERITAGE Family Study. Diabetes 54, 2251-2255. [CrossRef]

139. P. An, M. Teran-Garcia, T. Rice, T. Rankinen, S. J. Weisnagel, R. N. Bergman, R. C. Boston, S. Mandel, D. Stefanovski, A. S. Leon, J. S. Skinner, D. C. Rao, C. Bouchard. 2005. Genome-wide linkage scans for prediabetes phenotypes in response to 20 weeks of endurance exercise training in non-diabetic whites and blacks: the HERITAGE Family Study. Diabetologia 48, 1142-1149. [CrossRef]

140. Nicholas Frank, Carla S. Sommardahl, Hugo Eiler, Latisha L. Webb, Joseph W. Denhart, Ray C. Boston. 2005. Effects of oral administration of levothyroxine sodium on concentrations of plasma lipids, concentration and composition of very-low-density lipoproteins, and glucose dynamics in healthy adult mares. American Journal of Veterinary Research 66:10.2460/ajvr.2005.66.issue-6, 1032-1038. [CrossRef]

141. Dr. Raymond C. Boston, Peter J. Moate, Darko Stefanovski, Anne E. Sumner, Richard N. Bergman. 2005. AKA-Glucose: A Program for Kinetic and Epidemiological Analysis of Frequently Sampled Intravenous Glucose Tolerance Test Data Using Database Technology. Diabetes Technology \& Therapeutics 7:2, 298-307. [Abstract] [Full Text PDF] [Full Text PDF with Links]

142. David S. Kronfeld, Kimberley H. Treiber, Raymond J. Geor. 2005. Comparison of nonspecific indications and quantitative methods for the assessment of insulin resistance in horses and ponies. Journal of the American Veterinary Medical Association 226:10.2460/javma.2005.226.issue-5, 712-719. [CrossRef]

143. K. A. McLachlan, F. P. Alford. 2005. The impact of acute elevation of non-esterified fatty acids on insulin sensitivity and secretion in women with former gestational diabetes. Clinical Endocrinology 62:10.1111/cen.2005.62.issue-1, 79-84. [CrossRef]

144. Richard N. Bergman. 2005. Minimal Model: Perspective from 2005. Hormone Research 64, 8-15. [CrossRef]

145. R. Daniel Rudic, Peter McNamara, Anne-Maria Curtis, Raymond C. Boston, Satchidananda Panda, John B. Hogenesch, Garret A. FitzGerald. 2004. BMAL1 and CLOCK, Two Essential Components of the Circadian Clock, Are Involved in Glucose Homeostasis. PLoS Biology 2, e377. [CrossRef] 